\title{
Research on mathematical literacy in schools - Aim, approach and attention
}

\author{
Frode Olav Haara ${ }^{1}$, Oda Heidi Bolstad ${ }^{1}$ and Eirik S. Jenssen ${ }^{1}$ \\ ${ }^{1}$ Department of Teacher Education and Sports, Western Norway University of Applied Sciences, Sogndal, Norway \\ For correspondence: oda.heidi.bolstad@hvl.no
}

\begin{abstract}
The development of mathematical literacy in schools is of significant concern at the policy level, and research is an important source of information in this process. This review article focuses on areas of research interest identified in empirical projects on mathematical literacy, and how mathematical literacy in schools is approached by research. The following three main challenges are identified: both researchers and teachers are uncertain about how to develop students' mathematical literacy, specific attempts to work directly with mathematical literacy through mathematics alone have not been successful, and teaching for mathematical literacy appears to require non-traditional methods for teaching mathematics. More qualitative research is called for, with emphasis, for example, on classroom studies focusing on teachers' priorities regarding mathematical literacy, best-practice examples, or interventions in which teachers and researchers work together.
\end{abstract}

Keywords: mathematical literacy, review, empirical research

\section{Introduction}

Mathematical literacy is one of the key competencies highlighted by the Organization for Economic Cooperation and Development (OECD) $(2005,2009)$, and is described as follows:

an individual's capacity to identify and understand the role mathematics plays in the world, to make well-founded judgements and to use and engage with mathematics in ways that meet the needs of that individual's life as a constructive, concerned and reflective citizen (OECD, 2003, p. 15).

Mathematically literate students are able to analyse, reason, and communicate ideas effectively as they pose, formulate, solve, and interpret solutions to mathematical problems in a variety of situations and contexts (OECD, 2009, 2012). These contexts range from being purely mathematical to having no mathematical structure present or apparent at the outset and requiring the solver to introduce the mathematical structure. The definition concerns doing and using mathematics in situations that range from the everyday to the unusual and from the simple to the complex (OECD, 2009, 2012). Hence, development of students' mathematical literacy will influence their confidence and competence in mathematics and prepare them for the application and future learning of mathematics in higher education and outside of the classroom (OECD, 2003).

Mathematical literacy is one of the competencies measured through Programme for International Student Assessment (PISA) tests. PISA tests are comparative international tests aimed at assessing how well education systems prepare students for real life situations. PISA tests seek to assess the 
ability of 15-year-old students to apply what they have learned in school to non-school environments. Much of the research in the mathematical literacy field uses results from worldwide or national PISA tests that emphasize mathematical literacy in order to focus on implications for national school and social matters. However, some research focuses directly on mathematical literacy and teaching for mathematical literacy, and the research community is urged to focus on this approach: "The question of how to teach for mathematical literacy must be theoretically and empirically studied. When we consider the urgency of the issue, we should make sure that such research is given high priority" (Sfard, 2014, p. 141). An examination of priorities in the attention that research gives to mathematical literacy in teaching and learning will assist in addressing implications that arise for primary and lower secondary school teaching and for future research on mathematical literacy. However, no comprehensive review of current empirical research on the priorities within mathematical literacy research has been conducted.

This review article focuses on areas of research interest in empirical projects where mathematical literacy is highlighted. It includes quantitative and qualitative projects, studies in which mathematical literacy is emphasized in the development of data collection tools or in what is being measured, and studies that focus more on teachers' implementation of mathematical literacy in teaching and learning. The article aims to address research on mathematical literacy in primary and lower secondary school by bringing together and synthesizing the diverse body of current research, emphasizing the implications for teaching in the area, and pointing to areas that need to be addressed in future research. Within these parameters, we aim to present a systematic review of recent empirical studies, focusing on the following four key questions:

1. How is mathematical literacy conceptualized?

2. What methods have been used to examine emphasis on mathematical literacy in primary and lower secondary school?

3. What is the focus of attention in research on mathematical literacy?

4. What are the implications for primary and lower secondary school teaching, and recommendations for future research on mathematical literacy?

\section{Method}

\section{Review parameters}

One of the first written occurrences of the term mathematical literacy was given by the Commission of the National Council of Teachers of Mathematics (NCTM) in 1944 in the United States (Niss \& Jablonka, 2014). The NCTM stated that the school should ensure mathematical literacy for all who can achieve it, but did not provide a definition of the concept. According to Niss and Jablonka there is no universally accepted meaning of mathematical literacy, and a number of related notionscan be found in the mathematics education literature. Some authors use mathematical literacy, numeracy and quantitative literacy synonymously, while others distinguish between them. Other related concepts include critical mathematical literacy, mathemacy, matheracy and statistical literacy (Niss \& Jablonka, 2014).

The OECD (1999) appears to have given the first explicit definition of mathematical literacy (Niss \& Jablonka, 2014) and to a large extent, researchers define this concept as competence in accordance with the OECD definitions (1999, 2003, 2009, 2012).De Lange (2003) defined mathematical literacy as the 
comprehension and application of mathematics through reasoning, thinking and interpreting. Recently, other definitions of mathematical literacy have been attempted (Colwell \& Enderson, 2016); however, within mathematics education research, there seems to be wide agreement that mathematical literacy is a person's ability to engage in higher-order thinking skills specific to mathematics that allow the understanding and application of mathematics in real-life, everyday situations. Mathematical literacy is the ability to make use of mathematical knowledge, the ability to pose and solve mathematical problems in a variety of situations and the motivation to do so (OECD, 2003). There seems to be general consensus about the definition of the concept of mathematical literacy within research on mathematics teaching and learning, but there is uncertainty about what is emphasized in the interpretation of the OECD definition and about how it is applied to students' development of mathematical literacy. Therefore, in the present review, we studied the use of the mathematical literacy concept in various publications to identify appropriate keywords for the selection of relevant literature.

The selection process for the review consisted of three phases. In the first phase, we identified keywords related to mathematical literacy in domestic and international policy documents(e.g., Kunnskapsdepartementet, 2015; OECD, 2003, 2005; OECD, 2009), and in books and anthologies focusing on mathematics education (e.g., Bishop, Clements, Keitel, Kilpatrick, \& Leung, 2003; Pitici, 2014). In the second phase, we searched education databases (ERIC, Scopus, Science Direct) and the Web of Science citation database. The searches were limited to articles in English published after OECD launched the high impact Definition and Selection Of Key Competencies (DeSeCo) report (Allerup, Lindenskov, \& Weng, 2006; OECD, 2005), which means articles published from 2006 onwards, using only the key term "mathematical literacy". Because of the current high level of attention paid to this topic, we anticipated that it would be necessary to include the additional keywords identified in the first phase in our search, such as "school", "teach", "education" or "problem-solving". This proved to be incompatible with our aim of reaching the body of article publications from the international mathematical literacy research community. The searches were simply narrowed down too much by the addition of even one keyword to the main term "mathematical literacy". In the third phase, we removed duplicate articles, articles that were not empirical studies, articles that focused on higher education or on the upper secondary school level, and articles that were not published in peerreviewed journals. The resulting 28 publications form the basis of this review (see Appendix 1).

\section{Analysis}

We opened the process of analysis by dividing the articles between all three authors. We used a summary table for each of the articles, outlining each article's focus, setting (type of school and number of participants), methods and data sources, and identifying the implications of teaching for mathematical literacy in the reported research and subsequent implications for further research on mathematical literacy. The first author then combined these details into a single table and checked for inconsistencies or missing information. A brief summary of each article is shown in Annex 1. The conceptualization and application of a "mathematical literacy" definition in each article was identified and summarized. Factors that were considered to be influential in teaching for mathematical literacy were identified and categorized, as were identified implications and challenges related to the emphasis on mathematical literacy in school. 


\section{Results}

\section{Conceptualization of mathematical literacy}

Most of the articles studied in this review refer to PISA tests and OECD definitions of mathematical literacy (OECD, 1999, 2003, 2009, 2012). Several of the articles use data from PISA test results, and are therefore obliged to acknowledge the prevailing OECD definition at the time of testing, because the attention to mathematical literacy in the PISA tests is based on this definition. Some of the articles do not provide an explicit definition of mathematical literacy (e.g., Areepattamannil, 2014; Jürges, Schneider, Senkbeil, \& Carstensen, 2012; Roth, Ercikan, Simon, \& Fola, 2015; Ryan, 2013; Y1lmazer \& Masal, 2014). However, because they either refer to PISA testing, or use PISA test results as data samples, it is presumed they used the prevailing OECD definition at the time to represent their notion of the concept. Such a perspective verifies the use of the data collected and analysed by others to analyse the effects and implications of PISA data for domestic development (Koğar, 2015; Lin \& Tai, 2015).

In addition, some of the articles reviewed connect subject matter theories within mathematics education with the concept of mathematical literacy. A common factor for these articles is their interest regarding the teaching of mathematical literacy in school. Andrews refers to Kilpatrick, Swafford and Findell's (2001) five strands of mathematical proficiency-conceptual understanding, procedural fluency, strategic competence, adaptive reasoning, and productive disposition-and point to their alignment with "PISA's key objective, with respect to mathematical literacy, of assessing students' application of mathematical knowledge and skills to authentic settings, both within mathematics itself and more broadly"(Andrews, 2013, p. 189). Höfer and Beckmann (2009) refer to Jablonka (2003), who relates mathematical literacy to the following five elements: developing human capital, cultural identity, social change, environmental awareness, and evaluating mathematics. According to Höfer and Beckmann, "the core of mathematical literacy is formed by the ability to apply mathematical knowledge to various and context-related problems in a functional, flexible and practical way" (p. 224). Meaney (2007) applies a different approach. Rather than focusing on what mathematical literacy is, she uses Kaiser and Willander's (2005) hierarchy of levels of mathematical literacy as the framework for research on recognizing and teaching mathematical literacy. These levels are illiteracy (ignorance of basic mathematical concepts and methods), nominal literacy (minimal understanding of mathematical terms and topics, accompanied by naïve theoretical explanations and misconceptions), functional literacy (use of procedures for solving simple problems, but restricted to very specific contexts and lack in-depth understanding), conceptual and procedural literacy (some understanding of the structure and function of central mathematical ideas), and multidimensional literacy (contextual understanding of mathematics incorporating philosophical, historical and social dimensions); all of these levels refer to students' understanding and use of mathematical concepts. Gatabi, Stacey, and Gooya (2012) apply yet another approach, when they relate mathematical literacy to a single concept within mathematics. They see mathematical modelling as the key process in mathematical literacy. Mathematical modelling starts with an extra-mathematical world problem. The solver then has to formulate the problem in mathematical terms, solve it by applying mathematical concepts and procedures, interpret the solution to provide an answer, and check the answer for adequacy in answering the original question. Such an interpretation is supported by Edo, Hartono, and Putri (2013), who also closely relate mathematical literacy to modelling, but on three levels. Hence, they increase the complexity of the relation between modelling and mathematical literacy. 
They define mathematical literacy as an individual's capacity to formulate, employ and interpret mathematics. To formulate involves recognizing and identifying opportunities to use mathematics, providing mathematical structure to a problem presented in some contextualized form. To employ involves applying mathematical concepts, facts, procedures, and reasoning to solve mathematically formulated problems and obtain mathematical conclusions. Finally, to interpret involves reflecting upon mathematical solutions, results or conclusions and interpreting them in the context of real-life problems.

To summarize, the nuancedyet continuous development of the mathematical literacy definition given by the OECD seems to prevail within research on mathematical literacy, but researchers also show that they need to go beyond, or rather beneath, this definition when researching mathematics classroom activity. This seems to be because of the complexity of the prevailing OECD definition. It frames widely, and the researchers (and teachers) need to narrow the focus to only a few of the features of the OECD mathematical literacy concept to identify teaching development, change or impact on learning. For instance, Gatabi et al. (2012) found it necessary to closely relate mathematical literacy to mathematical modelling.

\section{Overview of research methods}

As stated in the introduction, one question of interest in this article relates to the methods used to examine mathematical literacy. To answer this question, the selected articles were categorized according to the countries in which the different studies were conducted, their methodological approach, the nature and size of the sample, and the source of the data.

Table 1. Data collection by country

\begin{tabular}{lc}
\hline Country & $\begin{array}{c}\text { Number of data } \\
\text { samples from each } \\
\text { country }\end{array}$ \\
\hline Turkey & 6 \\
Belgium** & 3 \\
Taiwan & 3 \\
Australia* & 2 \\
Finland & 2 \\
Germany & 2 \\
Indonesia & 2 \\
Israel & 2 \\
USA & 2 \\
Canada & 1 \\
China & 1 \\
Czech & 1 \\
England** & 1 \\
Hungary** & 1 \\
India & 1 \\
Iran* & 1 \\
New Zealand & 1 \\
Spain** & 1 \\
Sweden** & 1 \\
Total & 34 \\
\hline$*$ One &
\end{tabular}

* One study was carried out in both Iran and 


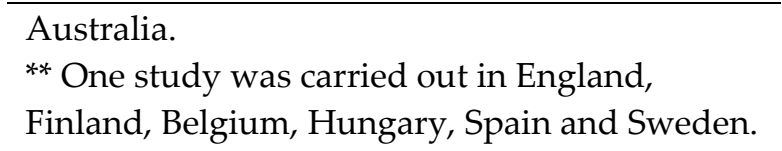

The studies were conducted worldwide, but with a clear majority of European and Asian contributions. Studi

es on mathematical literacy in primary and lower secondary school from nine European and six Asian countries were represented in the articles reviewed. In addition, studies were reported from both Oceania and North America. As indicated in Table 1, the largest group of studies (six) were conducted in Turkey. The strong representation of OECD countries is of course influenced by the explicit attention given to PISA tests in these countries since the first PISA test cycle in 2000.

Table 2. Methodological approaches and sample sizes

\begin{tabular}{llllll}
\hline Sample size & Actual range & Qualitative & Quantitative & Mixed methods & $\begin{array}{l}\text { Number of } \\
\text { studies }\end{array}$ \\
\hline Fewer than 50 & $3-48$ & 3 & 1 & 2 & 6 \\
$50-199$ & $71-107$ & 2 & 2 & 1 & 5 \\
$200-1000$ & $213-897$ & 1 & 3 & & 4 \\
Morethan 1000 & $1227-1,695,233$ & & 13 & & 13 \\
Total & & 6 & 19 & 3 & 28 \\
\hline
\end{tabular}

A clear predominance of quantitative methodological approaches (more than $67 \%$ of studies) was observed (see Table 2). Studies categorized as mixed methods used both qualitative and quantitative sources of data. In the studies that use data collected from informants, the sample sizes varied from 3 to $1,695,233$. The informants were students, teachers and teacher educators. Content analysis of mathematics text-books was also represented in the body of articles (Gatabi et al., 2012) (see Tables 2 and 3).

Table 3. Data sources

\begin{tabular}{lc}
\hline Type of data source & Number of studies \\
\hline PISA & 13 \\
Knowledge tests & 11 \\
Interviews & 7 \\
Video study & 4 \\
Text-books & 1 \\
Intervention & 1 \\
Questionnaire & 1 \\
\hline
\end{tabular}

The studies used a variety of approaches (see Table 3). The vast majority of studies analysed PISA test results, and the development, implementation and evaluation of knowledge tests (often described as PISA-like tasks), which provided descriptive information on the impact of students level of mathematical literacy, parameters influencing or influenced by students' mathematical literacy, or consequences of students' mathematical literacy level for society. One study collected data through Trends in International Mathematics and Science Study (TIMMS)-like tasks (Zikl, Havlíčková, Holoubková, Hrníčková, \& Volfová, 2015). The qualitative data were primarily interviews and video studies of teaching sequences. Three video studies emphasized teaching and one focused on student 
activity. In addition, the body of reviewed articles contained an intervention study (Tzohar-Rozen \& Kramarski, 2013), a document study (Gatabi et al., 2012), and a quasi-experimental study combining student knowledge tests with questionnaires (Chen \& Chiu, 2016) to collect data.

\section{Focus of attention in research on mathematical literacy}

First, some researchers seemed to use mathematical literacy as a way to catch the reader's eye(Van Hoof, Janssen, Verschaffel, \& Van Dooren, 2015; Van Hoof, Vandewalle, Verschaffel, \& Van Dooren, 2014; Zhao, Valcke, Desoete, Verhaeghe, \& Xu, 2011). We have reached such a view because we find it hard to argue for using mathematical literacy as a keyword or in the opening sentence of an article when the concept does not appear elsewhere in the article. Perhaps this is due to the wide and varied definitions of mathematical literacy given by the $\operatorname{OECD}(1999,2003,2009,2012)$. Second, the research articles studied in this review show that research on mathematical literacy is dominated by quantitative approaches, and does not focus on what goes on inside of the classroom. Some of the articles with a quantitative approach focus on what could be done in school(e.g., Zikl et al., 2015), but the majority focused on the outcomes of what actually goes on in school. Some of these articles used new or modified tests (e.g., Yllmazer \& Masal, 2014), but in several articles, results and previously collected and verified data from PISA tests were reanalysed with a focus on parameters other than competences in mathematics, particularly which affective factors might influence mathematical literacy (e.g, Aksu \& Güzeller, 2016; Ilbagi \& Akgun, 2013; İş Güzel \& Berbero囵u, 2010; Jürges et al., 2012; Koğar, 2015; Matteson, 2006; Papanastasiou \& Ferdig, 2006).

In some articles, however, the researchers chose a qualitative approach. These articles used data from interviews with students who were asked to explain what they were thinking and doing (Chen \& Chiu, 2016; Edo et al., 2013; Roth et al., 2015), or observation of teachers (Andrews, 2013; Höfer \& Beckmann, 2009). A few qualitative studies considered more than one perspective (Andrews, Ryve, Hemmi, \& Sayers, 2014; Dewantara, Zulkardi, \& Darmawijoyo, 2015; Meaney, 2007; Tzohar-Rozen \& Kramarski, 2013). They bring attention to what goes on in the classroom regarding mathematical literacy, and what might be done to teach mathematical literacy development. However, only a small proportion of the articles that met the parameters for this review actually focused on how teachers ought to work in the classroom to enable students to develop their mathematical literacy. Curricula, text-books and exams relate mathematical subjects to learning goal achievement, but they do not necessarily give attention to mathematical literacy (e.g, Gatabi et al., 2012; Jürges et al., 2012; Kunnskapsdepartementet, 2006; Ovayolu \& Kutlu, 2011). However, PISA tests are especially focused on this subject (Allerup et al., 2006). Research might therefore ask whether students in several countries actually work with the issues on which they are tested through PISA.

\section{Implications for primary and lower secondary school teaching}

Students' development of mathematical literacy in school seems to be a complex process influenced by a large set of variables (Zhao et al., 2011). Altogether, the reviewed articles point to three sets of crucial factors regarding this: teacher style and priorities (Höfer \& Beckmann, 2009; Kramarski \& Mizrachi, 2006; Lin \& Tai, 2015; Roth et al., 2015; Tai \& Lin, 2015), affective qualities (Aksu \& Güzeller, 2016; İş Güzel \& Berbero?lu, 2010; Tzohar-Rozen \& Kramarski, 2013), and students' perceptions of the classroom and school environment (Areepattamannil, 2014). Common among these factors is the teacher, and what the teacher does to enhance the emphasis on mathematical literacy in the classroom. The prioritizing of valid, practical and real-life related mathematics problems is highlighted 
(Dewantara et al., 2015; Matteson, 2006; Yllmazer \& Masal, 2014). This is important because considerable attention on students' conceptual understanding and procedural fluency alone, without systematic attempts to forge connections, does not provide recurrent opportunities for real-life problem-solving (Andrews, 2013). According to several researchers, problem-solving styles play an important role in mathematical literacy (Edo et al., 2013; Gatabi et al., 2012; Lin \& Tai, 2015), and students who do not adopt an active problem-solving attitude do not develop mathematical literacy to the same extent as those who do (Tai \& Lin, 2015). Furthermore, the classroom climate is negatively influenced by high anxiety and low confidence levels. According to İş Güzel and Berberoğlu (2010), both the interest and enjoyment of mathematics among students become negatively related to mathematical literacy when they experience that learning achievement and mathematical literacy are not the same. Scientific experiments make it possible to create situations in which formal knowledge and mathematical activities can be combined in understanding the subject matter (Höfer \& Beckmann, 2009; Ovayolu \& Kutlu, 2011). To support mathematical literacy, teachers need to devise a style of teaching that includes conventional and applied knowledge. As a consequence, Lin and Tai (2015) suggest that teachers must consider methods for explicitly teaching various learning strategies to improve students' mathematical literacy, including problem analysis and self-regulation development (Kramarski \& Mizrachi, 2006; Tzohar-Rozen \& Kramarski, 2013). This approach will rely on the presentation of real-life problems and open-ended interpretation problems (Dewantara et al., 2015; Ovayolu \& Kutlu, 2011; Y1lmazer \& Masal, 2014), competence in reading and analysis of problems (Andrews et al., 2014), and the ability to approach problems from a critical perspective. Finally, students' perceptions of the classroom and school environment will be influenced by teaching priorities(İş Güzel \& Berbero[lu, 2010). Students need to be allowed to discuss, to co-operate in the learning process, and to experience an open-minded and inclusive learning environment in which the learning process prevails. Within a mathematics classroom that does not acknowledge the effect of affective qualities such as self-efficacy, attitudes regarding mathematics, study discipline, anxiety, and interest (Aksu \& Güzeller, 2016), the environment for students' development of mathematical literacy will suffer (Areepattamannil, 2014).

\section{Discussion}

According to the body of published research available for this review on mathematical literacy in schools, identifying what teachers and schools ought to do to enhance students' development of mathematical literacy seems to be almost as big a challenge as teaching for mathematical literacy itself. The concept of mathematical literacy is quite widely defined by the $\operatorname{OECD}(1999,2003,2009,2012)$, and seems to be a political rather than a subject matter concept. Political concepts may be revised in accordance with changes in political needs and desires. Only to some extent did we find articles in this review that take a stand on the content of a mathematical literacy definition from a subject matter perspective (Andrews, 2013; Edo et al., 2013; Gatabi et al., 2012; Höfer \& Beckmann, 2009; Meaney, 2007). The authors of these articles need to interpret the definition within the field of mathematics to narrow down the number of influential factors when conducting qualitative studies on the operationalization of the concept in schools. The lack of clarity around the concept makes it difficult for teachers to know what to do. Even though the definition of the concept changes from document to document (OECD, 1999, 2003, 2009, 2012), policy documents are quite clear on the expectations regarding the prioritization of mathematical literacy in schools. The nuanced yet continuous development of the concept makes teaching for mathematical literacy challenging because the 
continuous development of the definition stemming from political influence on the concept makes revised interpretations necessary. This makes it difficult for teachers to find help in the text-books they use in their teaching or in the prevailing curriculum.

Furthermore, researchers struggle in the attempt to establish a clear picture of teacher priorities needed to fulfil political expectations; therefore, there also does not seem to be much guidance for teachers in the research. Research on PISA test results seems to be aimed towards further explanations or the social consequences of results that have already been established. This is important knowledge about students' mathematical literacy development, but it does not help the teacher. We find it rather puzzling that the vast majority of the research articles on mathematical literacy in this review did not emphasize qualitative approaches to what goes on in the mathematical literacy-enhancing classroom. It seems that the research environment should give more priority to the introductory question of how to teach for mathematical literacy (Sfard, 2014). From this review, we have found some crucial points on this issue. First, it seems that teachers do not know what to prioritize, and that they do not get much help from the curriculum or text-books. Second, it seems that specific attempts to work directly with mathematical literacy through mathematics alone only influence students' mathematical literacy to a small extent. Third, it seems that teaching for mathematical literacy calls for something other than the traditional teaching of mathematics, in which individual task solving and a well-defined classroom structure prevail. This implies that changes should to be made to enable mathematics teachers to cope with these three challenges. A more holistic approach to the teaching of mathematics might offer students a fair chance of developing their mathematical literacy to some extent while they still are in primary or lower secondary school.

This review found that extensive attention was given to quantitative data regarding student performance on mathematical literacy-related problems. Further prioritizing such research would not be expected to address what could be done in the classroom to improve this issue. Teachers are uncertain about what to do, and specific attempts to work directly with mathematical literacy through mathematics alone have not been successful. Furthermore, it seems that teaching for mathematical literacy calls for something other than traditional mathematics teaching. Research-based answers to these challenges will help both teachers and the research community to pave the way for teaching priorities that will enhance mathematical literacy development. For such answers to be found, research on mathematical literacy in schools needs to change its perspective. In addition, more qualitative projects, such as classroom studies that focus on teachers' priorities regarding mathematical literacy and studies of best-practice, or research-based interventions in which teachers and researchers co-operate, are also needed.

\section{Conclusions and implications for future research on mathematical literacy}

The present review revealed that research in the field of mathematical literacy in schools faces a number of complex challenges. The rather nuanced and continuously developing definition of the mathematical literacy concept makes it somewhat difficult for teachers and the research community to decide how to teach for mathematical literacy, and subsequently makes it challenging for teachers to gain valid and reliable guidance. 
The aim of future research on mathematical literacy should be to fulfil Sfard's (2014, p. 141) request for theoretical and empirical studies regarding how to teach for mathematical literacy. The approach to such a quest seems to be through increased emphasis on qualitative research, for instance, through studies of best-practice and research projects involving practising teachers. Therefore, the research community's attention needs to shift from nurturing data and findings that highlight student results on mathematical literacy tests to research on what to do in order to improve the students' opportunities to develop mathematical literacy. A starting point for such a shift in focus could be to examine how mathematical literacy is understood, facilitated and experienced in schools.

\section{Acknowledgements}

We would like to acknowledge the librarians at Sogn og Fjordane University College for their assistance in providing us with the literature used in the preparation of this review article.

\section{References}

Aksu, G., \& Güzeller, C. O. (2016). Classification of PISA 2012 mathematical literacy scores using Decision-Tree Method: Turkey sampling. Egitim ve Bilim, 41(185), 101-122.

Allerup, P., Lindenskov, L., \& Weng, P. (2006). “Growing up" - The story behind two items from PISA 2003. In J. Mejding \& A. Roe (Eds.), Northern lights on PISA 2003: A reflection from the Nordic countries (pp. 59-72). København: Nordic Council of Ministers.

Andrews, P. (2013). Finnish mathematics teaching from a reform perspective: A video-based case-study analysis. Comparative Education Review, 57(2), 189-211.

Andrews, P., Ryve, A., Hemmi, K., \& Sayers, J. (2014). PISA, TIMSS and Finnish mathematics teaching: an enigma in search of an explanation. Educational Studies in Mathematics, 87(1), 7-26. doi:10.1007/s10649-014-9545-3

Areepattamannil, S. (2014). International note: What factors are associated with reading, mathematics, and science literacy of Indian adolescents? A multilevel examination. Journal of Adolescence, 37(4), 367-372. doi:10.1016/j.adolescence.2014.02.007

Bishop, A. J., Clements, M. A., Keitel, C., Kilpatrick, J., \& Leung, F. K. S. (Eds.). (2003). Second international handbook of mathematics education. Dordrecht: Kluwer Academic Publishers.

Chen, C. H., \& Chiu, C. H. (2016). Collaboration scripts for enhancing metacognitive self-regulation and mathematics literacy. International Journal of Science and Mathematics Education, 14(2), 263-280. doi:10.1007/s10763-015-9681-y

Colwell, J., \& Enderson, M. C. (2016). "When I hear literacy": Using pre-service teachers' perceptions of mathematical literacy to inform program changes in teacher education. Teaching \& Teacher Education, 53, 63-74. doi:10.1016/j.tate.2015.11.001

De Lange, J. (2003). Mathematics for Literacy. In B. L. Madison \& L. A. Steen (Eds.), Quantitative literacy. Why numeracy matters for schools and colleges (pp. 75-89). Princeton, NJ: The National Council on Education and the Disciplines.

Dewantara, A. H., Zulkardi, \& Darmawijoyo. (2015). Assessing seventh graders' mathematical literacy in solving PISA-like tasks. Indonesian Mathematical Society Journal on Mathematics Education, 6(2), 39-49.

Edo, S. I., Hartono, Y., \& Putri, R. I. I. (2013). Investigating secondary school students' difficulties in modeling problems PISAmodel Level 5 and 6. Indonesian Mathematical Society Journal on Mathematics Education, 4(1), 41-58.

Gatabi, A. R., Stacey, K., \& Gooya, Z. (2012). Investigating grade nine textbook problems for characteristics related to mathematical literacy. Mathematics Education Research Journal, 24(4), 403-421. doi:10.1007/s13394-012-0052-5

Höfer, T., \& Beckmann, A. (2009). Supporting mathematical literacy: Examples from a cross-curricular project. International Journal on Mathematics Education, 41(1), 223-230. doi:10.1007/s11858-008-0117-9

Ilbagi, E. A., \& Akgun, L. (2013). An Investigation of the mathematical literacy of students aged 15 in terms of PISA 2003 mathematical literacy questions: Results from Turkey. International Journal of Progressive Education, 9(3), $194-217$.

İş Güzel, Ç., \& Berbero?lu, G. (2010). Students' affective characteristics and their relation to mathematical literacy measures in the Programme for International Student Assessment (PISA) 2003. Egitim Arastirmalari - Eurasian Journal of Educational Research(40), 93-113.

Jürges, H., Schneider, K., Senkbeil, M., \& Carstensen, C. H. (2012). Assessment drives learning: The effect of central exit exams on curricular knowledge and mathematical literacy. Economics of Education Review, 31(1), 56-65. doi:http://dx.doi.org/10.1016/j.econedurev.2011.08.007

Kilpatrick, J., Swafford, J., Findell, B., Mathematics Learning Study, C., National Research Council Center for Education, D. o. b., \& social sciences, e. (2001). Adding it up: Helping children learn mathematics. Washington, DC: National Academy Press.

Koğar, H. (2015). Examination of factors affecting PISA 2012 mathematical literacy through mediation model. Egitim ve Bilim, 40(179), 45-55. doi:10.15390/EB.2015.4445

Kramarski, B., \& Mizrachi, N. (2006). Online discussion and self-regulated learning: Effects of instructional methods on mathematical literacy. Journal of Educational Research, 99(4), 218-229. doi:10.3200/JOER.99.4.218-231 
Kunnskapsdepartementet. (2006). Læreplanverket for Kunnskapsløftet. Retrieved from http://www.udir.no/laring-ogtrivsel/lareplanverket/.

Kunnskapsdepartementet. (2015). Tett på realfag. Nasjonal strategi for realfag i barnehagen og grunnopplæringen (2015-2019). Retrieved from https://www.regjeringen.no/contentassets/869faa81d1d740d297776740e67e3e65/kd_realfagsstrategi.pdf.

Lin, S. W., \& Tai, W. C. (2015). Latent class analysis of atudents' mathematics learning strategies and the relationship between learning strategy and mathematical literacy. Universal Journal of Educational Research, 3(6), 390-395.

Matteson, S. M. (2006). Mathematical literacy and standardized mathematical assessments. Reading Psychology, 27, $205-233$.

Meaney, T. (2007). Weighing up the influence of context on judgements of mathematical literacy. International Journal of Science and Mathematics Education, 5(4), 681-704. doi:10.1007/s10763-007-9093-8

Niss, M., \& Jablonka, E. (2014). Mathematical Literacy. In S. Lerman (Ed.), Encyclopedia of Mathematics Education (pp. 391-396). Dordrecht: Springer.

OECD. (1999). Measuring student knowledge and skills. A new framework for assessment. Paris: OECD Publications Retrieved from https://www.oecd.org/edu/school/programmeforinternationalstudentassessmentpisa/33693997.pdf.

OECD. (2003). The PISA 2003 assessment framework - mathematics, reading, science and problem solving knowledge and skills. Paris: OECD Publications.

OECD. (2005). The definition and selection of key competencies. Executive summary. Retrieved from https://www.oecd.org/pisa/35070367.pdf.

OECD. (2009). PISA 2009 assessment framework. Key competencies in reading, mathematics and science. Retrieved from https://www.oecd.org/pisa/pisaproducts/44455820.pdf.

OECD. (2012). PISA 2012 Assessment and analytical framework. Mathematics, reading, science, problem solving and financial literacy. Retrieved from https://www.oecd.org/pisa/pisaproducts/PISA\%202012\%20framework\%20e-book_final.pdf.

Ovayolu, Ö., \& Kutlu, Ö. (2011). The range of scores in competency clusters of turkish students in mathematics sub-test according to pisa 2006. Procedia - Social and Behavioral Sciences, 15, 17-26. doi:http://dx.doi.org/10.1016/j.sbspro.2011.03.043

Papanastasiou, E. C., \& Ferdig, R. E. (2006). Computer use and mathematical literacy: An analysis of existing and potential relationships. Journal of Computers in Mathematics and Science Teaching, 25(4), 361-371.

Pitici, M. (Ed.) (2014). The best writing on mathematics 2013. Princeton, NJ: Princeton University Press.

Roth, W.-M., Ercikan, K., Simon, M., \& Fola, R. (2015). The assessment of mathematical literacy of linguistic minority students: Results of a multi-method investigation. Journal of Mathematical Behavior, 40, 88-105. doi:10.1016/j.jmathb.2015.01.004

Ryan, C. (2013). What is behind the decline in student achievement in Australia? Economics of Education Review, 37, $226-239$. doi:10.1016/j.econedurev.2013.08.008

Sfard, A. (2014). Why mathematics? What mathematics? In M. Pitici (Ed.), The best writing on mathematics 2013. Princeton, NJ: Princeton University Press.

Tai, W. C., \& Lin, S. W. (2015). Relationship between problem-solving style and mathematical literacy. Educational Research and Reviews, 10(11), 1480-1486.

Tzohar-Rozen, M., \& Kramarski, B. (2013). How does an affective self-regulation program promote mathematical literacy in young students? Hellenic Journal of Psychology, 10(3), 211-234.

Van Hoof, J., Janssen, R., Verschaffel, L., \& Van Dooren, W. (2015). Inhibiting natural knowledge in fourth graders: Towards a comprehensive test instrument. ZDM - Mathematics Education, 47(5), 849-857. doi:10.1007/s11858-014-0650-7

Van Hoof, J., Vandewalle, J., Verschaffel, L., \& Van Dooren, W. (2014). In search for the natural number bias in secondary school students' interpretation of the effect of arithmetical operations. Learning and Instruction. doi:10.1016/j.learninstruc.2014.03.004

Yilmazer, G., \& Masal, M. (2014). The relationship between secondary school students' arithmetic performance and their mathematical literacy. Procedia - Social and Behavioral Sciences, 152, 619-623. doi:http://dx.doi.org/10.1016/j.sbspro.2014.09.253

Zhao, N., Valcke, M., Desoete, A., Verhaeghe, J., \& Xu, K. (2011). A multilevel analysis on predicting mathematics performance in Chinese primary schools: Implications for practice. Asia-Pacific Education Researcher, 20(3), 503-520.

Zikl, P., Havlíčková, K., Holoubková, N., Hrníčková, K., \& Volfová, M. (2015). Mathematical literacy of pupils with mild intellectual disabilities. Procedia - Social and Behavioral Sciences, 174, 2582-2589. doi:http://dx.doi.org/10.1016/j.sbspro.2015.01.936 


\section{Appendix1}

Details of publications reviewed $(\mathrm{N}=28)$

\begin{tabular}{|c|c|c|c|c|c|}
\hline Reference & $\begin{array}{l}\text { Focus of } \\
\text { attention }\end{array}$ & $\begin{array}{l}\text { Setting } \\
\text { (informants, } \\
\text { type of } \\
\text { school, } \\
\text { number of } \\
\text { participants) }\end{array}$ & $\begin{array}{l}\text { Method, } \\
\text { data } \\
\text { sources }\end{array}$ & $\begin{array}{l}\text { Implications } \\
\text { for teaching } \\
\text { for } \\
\text { mathematic } \\
\text { al literacy }\end{array}$ & $\begin{array}{l}\text { Recommendati } \\
\text { ons for further } \\
\text { research on } \\
\text { mathematical } \\
\text { literacy }\end{array}$ \\
\hline $\begin{array}{l}\text { Aksu\&OktayGüzel } \\
\text { ler (2016) }\end{array}$ & $\begin{array}{l}\text { Attempt to } \\
\text { classify } \\
\text { successful } \\
\text { and } \\
\text { unsuccessfu } \\
\text { l students in } \\
\text { terms of } \\
\text { mathematic } \\
\text { al literacy } \\
\text { according to } \\
\text { interest in } \\
\text { the course, } \\
\text { attitude, } \\
\text { motivation, } \\
\text { perception, } \\
\text { self-efficacy, } \\
\text { anxiety and } \\
\text { study } \\
\text { discipline } \\
\text { variables, } \\
\text { and to } \\
\text { determine } \\
\text { the effect of } \\
\text { these } \\
\text { variables on } \\
\text { classificatio } \\
\text { n. }\end{array}$ & $\begin{array}{l}\mathrm{N}=1391 \text { 15- } \\
\text { year-old } \\
\text { students from } \\
\text { Turkey }\end{array}$ & $\begin{array}{l}\text { Quantitative } \\
\text { data from } \\
\text { PISA } 2012 \\
\text { CHAID } \\
\text { analysis } \\
\text { (decision- } \\
\text { tree } \\
\text { technique), } \\
\text { SPSS and } \\
\text { WEKA } \\
\text { software }\end{array}$ & $\begin{array}{l}\text { Affective } \\
\text { qualities } \\
\text { such as self- } \\
\text { efficacy, } \\
\text { attitude, } \\
\text { study } \\
\text { discipline, } \\
\text { anxiety and } \\
\text { interest } \\
\text { should be } \\
\text { developed to } \\
\text { ensure } \\
\text { higher } \\
\text { positioning } \\
\text { for Turkey } \\
\text { in large tests } \\
\text { like PISA. } \\
\text { This calls for } \\
\text { changes in } \\
\text { the } \\
\text { curriculum } \\
\text { and changes } \\
\text { that consider } \\
\text { the affective } \\
\text { qualities } \\
\text { instead of } \\
\text { focusing on } \\
\text { merely } \\
\text { cognitive } \\
\text { qualities in } \\
\text { course } \\
\text { programs. } \\
\text { More } \\
\text { emphasis } \\
\text { should be } \\
\text { placed on } \\
\text { the self- } \\
\text { efficacy } \\
\text { perception, } \\
\text { course } \\
\text { attitude and } \\
\text { anxiety for } \\
\text { the Turkey }\end{array}$ & $\begin{array}{l}\text { Complete } \\
\text { similar studies } \\
\text { involving other } \\
\text { countries, and } \\
\text { future } \\
\text { collections of } \\
\text { PISA data from } \\
\text { the Turkey } \\
\text { sample. } \\
\text { It is also } \\
\text { recommended } \\
\text { that the } \\
\text { classification } \\
\text { results with } \\
\text { respect to } \\
\text { mathematical } \\
\text { literacy should } \\
\text { be retested with } \\
\text { different } \\
\text { analysis } \\
\text { methods. }\end{array}$ \\
\hline
\end{tabular}




\begin{tabular}{|c|c|c|c|c|c|}
\hline Reference & $\begin{array}{l}\text { Focus of } \\
\text { attention }\end{array}$ & $\begin{array}{l}\text { Setting } \\
\text { (informants, } \\
\text { type of } \\
\text { school, } \\
\text { number of } \\
\text { participants) }\end{array}$ & $\begin{array}{l}\text { Method, } \\
\text { data } \\
\text { sources }\end{array}$ & $\begin{array}{l}\text { Implications } \\
\text { for teaching } \\
\text { for } \\
\text { mathematic } \\
\text { al literacy }\end{array}$ & $\begin{array}{l}\text { Recommendati } \\
\text { ons for further } \\
\text { research on } \\
\text { mathematical } \\
\text { literacy }\end{array}$ \\
\hline & & & & $\begin{array}{l}\text { sample for } \\
\text { mathematica } \\
1 \text { literacy. }\end{array}$ & \\
\hline Andrews (2013) & $\begin{array}{l}\text { How } \\
\text { teachers } \\
\text { conceptuali } \\
\text { ze and } \\
\text { present } \\
\text { mathematic } \\
\text { s to } \\
\text { students } \\
\text { framed } \\
\text { against the } \\
\text { five strands } \\
\text { of } \\
\text { mathematic } \\
\text { al } \\
\text { proficiencyo } \\
\text { f Kilpatrick } \\
\text { et al. (2001): } \\
\text { - Conceptua } \\
\quad \text { l } \\
\quad \text { underst } \\
\text { anding } \\
\text { - Procedural } \\
\quad \text { fluency } \\
\text { - Strategic } \\
\text { compet } \\
\text { ence } \\
\text { - Adaptive } \\
\text { reasoni } \\
\text { ng } \\
\text { - Productive } \\
\quad \text { disposit } \\
\text { ion }\end{array}$ & $\begin{array}{l}\mathrm{N}=4 \text { teachers } \\
\text { in Finnish } \\
\text { comprehensiv } \\
\text { e schools }\end{array}$ & $\begin{array}{l}\text { Qualitative } \\
\text { research } \\
\text { Video-based } \\
\text { case-study } \\
\text { of } 4-5 \\
\text { successive } \\
\text { lessons }\end{array}$ & $\begin{array}{l}\text { Considerabl } \\
\text { e attention is } \\
\text { focused on } \\
\text { students' } \\
\text { conceptual } \\
\text { understandi } \\
\text { ng and } \\
\text { procedural } \\
\text { fluency, but } \\
\text { there is an } \\
\text { absence of } \\
\text { any } \\
\text { systematic } \\
\text { attempt to } \\
\text { forge } \\
\text { connections. } \\
\text { Few } \\
\text { opportunitie } \\
\text { s for real life } \\
\text { problem- } \\
\text { solving. }\end{array}$ & $\begin{array}{l}\text { Explore the } \\
\text { reason for } \\
\text { Finnish } \\
\text { students' } \\
\text { repeated PISA } \\
\text { success, perhaps } \\
\text { byexamining } \\
\text { factors external } \\
\text { to individual } \\
\text { classrooms. }\end{array}$ \\
\hline $\begin{array}{l}\text { Andrews, Ryve, } \\
\text { Hemmi \& Sayers } \\
\text { (2014) }\end{array}$ & $\begin{array}{l}\text { The } \\
\text { resonance } \\
\text { between } \\
\text { classroom } \\
\text { practice and } \\
\text { the } \\
\text { mathematic } \\
\text { al literacy } \\
\text { component } \\
\text { of the PISA } \\
\text { assessment }\end{array}$ & $\begin{array}{l}\text { Twenty } \\
\text { mathematics } \\
\text { teachers (four } \\
\text { each from } \\
\text { England, } \\
\text { Finland, } \\
\text { Belgium, } \\
\text { Hungary and } \\
\text { Spain) } \\
\text { A few teacher }\end{array}$ & $\begin{array}{l}\text { Qualitative } \\
\text { study } \\
\text { Two } \\
\text { unrelated } \\
\text { data sets: } \\
\text { Data set 1: } \\
\text { Video study } \\
\text { of } \\
\text { mathematics } \\
\text { teaching }\end{array}$ & $\begin{array}{l}\text { In Finland, it } \\
\text { seems that it } \\
\text { is more } \\
\text { common to } \\
\text { involve } \\
\text { parents in } \\
\text { homework } \\
\text { tasks. } \\
\text { It is possible } \\
\text { that Finns }\end{array}$ & $\begin{array}{l}\text { Is the } \\
\text { mathematics } \\
\text { education } \\
\text { research } \\
\text { community } \\
\text { overestimating } \\
\text { the influence of } \\
\text { classroom } \\
\text { interaction on } \\
\text { student } \\
\text { learning? }\end{array}$ \\
\hline
\end{tabular}




\begin{tabular}{|c|c|c|c|c|c|}
\hline Reference & $\begin{array}{l}\text { Focus of } \\
\text { attention }\end{array}$ & $\begin{array}{l}\text { Setting } \\
\text { (informants, } \\
\text { type of } \\
\text { school, } \\
\text { number of } \\
\text { participants) }\end{array}$ & $\begin{array}{l}\text { Method, } \\
\text { data } \\
\text { sources }\end{array}$ & $\begin{array}{l}\text { Implications } \\
\text { for teaching } \\
\text { for } \\
\text { mathematic } \\
\text { al literacy }\end{array}$ & $\begin{array}{l}\text { Recommendati } \\
\text { ons for further } \\
\text { research on } \\
\text { mathematical } \\
\text { literacy }\end{array}$ \\
\hline & framework. & $\begin{array}{l}\text { educators in } \\
\text { Finland (two } \\
\text { small groups) } \\
\text { and Sweden } \\
\text { (individual) }\end{array}$ & $\begin{array}{l}\text { undertaken } \\
\text { in England, } \\
\text { Finland, } \\
\text { Flanders, } \\
\text { Hungary } \\
\text { and Spain } \\
\text { (focused on } \\
\text { how four } \\
\text { teachers in } \\
\text { each } \\
\text { country, } \\
\text { selected } \\
\text { against local } \\
\text { criteria of } \\
\text { quality, } \\
\text { typically } \\
\text { present } \\
\text { mathematics } \\
\text { to their } \\
\text { students), } \\
\text { and } \\
\text { translated } \\
\text { transcripts } \\
\text { (into } \\
\text { English). } \\
\text { Dataset 2: } \\
\text { Interview } \\
\text { and focus- } \\
\text { group } \\
\text { interviews } \\
\text { (two) with } \\
\text { Swedish and } \\
\text { Finnish } \\
\text { teacher } \\
\text { educators, } \\
\text { respectively }\end{array}$ & $\begin{array}{l}\text { excel on } \\
\text { language- } \\
\text { based tests } \\
\text { of } \\
\text { mathematica } \\
\text { l competence } \\
\text { such as PISA } \\
\text { not because } \\
\text { they are } \\
\text { particularly } \\
\text { mathematica } \\
\text { lly } \\
\text { competent- } \\
\text { their TIMSS } \\
\text { score } \\
\text { suggest they } \\
\text { are not-but } \\
\text { because they } \\
\text { are highly } \\
\text { competent } \\
\text { readers. }\end{array}$ & \\
\hline $\begin{array}{l}\text { Areepattamannil } \\
(2014)\end{array}$ & $\begin{array}{l}\text { Factors } \\
\text { related to } \\
\text { adolescents' } \\
\text { reading, } \\
\text { mathematic } \\
\text { s and } \\
\text { science } \\
\text { literacy }\end{array}$ & $\begin{array}{l}\mathrm{N}=482615- \\
\text { year-old } \\
\text { students from } \\
\text { India }\end{array}$ & $\begin{array}{l}\text { Quantitative } \\
\text { study } \\
\text { PISA } 2009 \\
\text { test results }\end{array}$ & $\begin{array}{l}\text { The study } \\
\text { underlines } \\
\text { the } \\
\text { relationship } \\
\text { between } \\
\text { gender, } \\
\text { metacognitiv } \\
\text { e learning } \\
\text { strategies } \\
\text { and }\end{array}$ & $\begin{array}{l}\text { Research to } \\
\text { better } \\
\text { understand } \\
\text { student and } \\
\text { schoollevel } \\
\text { predictors that } \\
\text { can be found to } \\
\text { be related and } \\
\text { unrelated to } \\
\text { academic }\end{array}$ \\
\hline
\end{tabular}




\begin{tabular}{|c|c|c|c|c|c|}
\hline Reference & $\begin{array}{l}\text { Focus of } \\
\text { attention }\end{array}$ & $\begin{array}{l}\text { Setting } \\
\text { (informants, } \\
\text { type of } \\
\text { school, } \\
\text { number of } \\
\text { participants) }\end{array}$ & $\begin{array}{l}\text { Method, } \\
\text { data } \\
\text { sources }\end{array}$ & $\begin{array}{l}\text { Implications } \\
\text { for teaching } \\
\text { for } \\
\text { mathematic } \\
\text { al literacy }\end{array}$ & $\begin{array}{l}\text { Recommendati } \\
\text { ons for further } \\
\text { research on } \\
\text { mathematical } \\
\text { literacy }\end{array}$ \\
\hline & & & & $\begin{array}{l}\text { students' } \\
\text { positive } \\
\text { perceptions } \\
\text { of the } \\
\text { classroom } \\
\text { and school } \\
\text { environment } \\
\text { to academic } \\
\text { performance }\end{array}$ & performance. \\
\hline $\begin{array}{l}\text { Chen \& Chiu } \\
\text { (2016) }\end{array}$ & $\begin{array}{l}\text { Examine the } \\
\text { impact of } \\
\text { use of } \\
\text { computer- } \\
\text { based } \\
\text { collaboratio } \\
\text { n scripts on } \\
\text { primary } \\
\text { school } \\
\text { students' } \\
\text { metacogniti } \\
\text { ve self- } \\
\text { regulation } \\
\text { and } \\
\text { mathematic } \\
\text { al literacy }\end{array}$ & $\begin{array}{l}\mathrm{N}=80 \text { fifth- } \\
\text { grade students } \\
\text { from Taiwan }\end{array}$ & $\begin{array}{l}\text { Quasi- } \\
\text { experimenta } \\
\text { l study } \\
\text { In groups, } \\
\text { students } \\
\text { carried out a } \\
\text { design } \\
\text { project using } \\
\text { tessellation } \\
\text { on } \\
\text { computers } \\
\text { in three } \\
\text { sequential } \\
\text { phases, with } \\
\text { a plenary } \\
\text { session after } \\
\text { each phase } \\
\text { to sharethe } \\
\text { products } \\
\text { with the } \\
\text { other } \\
\text { students. } \\
\text { The students } \\
\text { answered a } \\
\text { questionnair } \\
\text { e after each } \\
\text { phase to } \\
\text { provide data } \\
\text { on } \\
\text { metacogniti } \\
\text { ve self- } \\
\text { regulation. } \\
\text { Mathematics } \\
\text { test }\end{array}$ & $\begin{array}{l}\text { Working } \\
\text { with support } \\
\text { of } \\
\text { collaboration } \\
\text { scripts } \\
\text { positively } \\
\text { impacts } \\
\text { metacognitiv } \\
\text { e self- } \\
\text { regulation in } \\
\text { the } \\
\text { controlling } \\
\text { aspect of the } \\
\text { script and } \\
\text { mathematics } \\
\text { achievement } \\
\text {. No } \\
\text { registration } \\
\text { of impact on } \\
\text { mathematica } \\
1 \text { literacy } \\
\text { achievement } \\
\text {. }\end{array}$ & $\begin{array}{l}\text { Similar studies } \\
\text { with older } \\
\text { students are } \\
\text { needed, as is a } \\
\text { comparison } \\
\text { between the use } \\
\text { of computerized } \\
\text { scripts in face- } \\
\text { to-face and } \\
\text { computer- } \\
\text { mediated } \\
\text { collaborative } \\
\text { learning and } \\
\text { those given by a } \\
\text { live teacher. } \\
\text { Further studies } \\
\text { are needed on } \\
\text { students' } \\
\text { metacognition } \\
\text { and academic } \\
\text { achievement. }\end{array}$ \\
\hline
\end{tabular}




\begin{tabular}{|c|c|c|c|c|c|}
\hline Reference & $\begin{array}{l}\text { Focus of } \\
\text { attention }\end{array}$ & $\begin{array}{l}\text { Setting } \\
\text { (informants, } \\
\text { type of } \\
\text { school, } \\
\text { number of } \\
\text { participants) }\end{array}$ & $\begin{array}{l}\text { Method, } \\
\text { data } \\
\text { sources }\end{array}$ & $\begin{array}{l}\text { Implications } \\
\text { for teaching } \\
\text { for } \\
\text { mathematic } \\
\text { al literacy }\end{array}$ & $\begin{array}{l}\text { Recommendati } \\
\text { ons for further } \\
\text { research on } \\
\text { mathematical } \\
\text { literacy }\end{array}$ \\
\hline & & & $\begin{array}{l}\text { developed } \\
\text { to measure } \\
\text { students' } \\
\text { mathematica } \\
1 \text { literacy } \\
\text { achievement } \\
\text { in the } \\
\text { literacy area } \\
\text { "space and } \\
\text { shape" with } \\
\text { an emphasis } \\
\text { on plane } \\
\text { geometry. } \\
\text { Quantitative } \\
\text { analysis }\end{array}$ & & \\
\hline $\begin{array}{l}\text { Dewantara, } \\
\text { Zulkardi\&Darmaw } \\
\text { ijoyo (2015) }\end{array}$ & $\begin{array}{l}\text { The } \\
\text { activation of } \\
\text { fundamenta } \\
\text { mathematic } \\
\text { al } \\
\text { capabilities } \\
\text { that } \\
\text { underpin } \\
\text { the process } \\
\text { of } \\
\text { mathematic } \\
\text { al literacy. } \\
\text { The } \\
\text { potential } \\
\text { effects of a } \\
\text { set of PISA- } \\
\text { like } \\
\text { problems in } \\
\text { developing } \\
\text { students' } \\
\text { mathematic } \\
\text { al literacy. }\end{array}$ & $\begin{array}{l}\mathrm{N}=28 \text { seventh- } \\
\text { grade students } \\
\text { from } \\
\text { Indonesia }\end{array}$ & $\begin{array}{l}\text { Qualitative } \\
\text { research } \\
\text { Students' } \\
\text { test results } \\
\text { and } \\
\text { interviews }\end{array}$ & $\begin{array}{l}\text { Valid and } \\
\text { practical } \\
\text { PISA-like } \\
\text { mathematics } \\
\text { problems } \\
\text { (developed } \\
\text { in this } \\
\text { study) have } \\
\text { the potential } \\
\text { to develop } \\
\text { students' } \\
\text { mathematica } \\
1 \text { literacy. }\end{array}$ & \\
\hline $\begin{array}{l}\text { Edo, Hartono } \\
\& \text { Putri (2013) }\end{array}$ & $\begin{array}{l}\text { Secondary } \\
\text { school } \\
\text { students' } \\
\text { difficulties } \\
\text { in } \\
\text { modelling }\end{array}$ & $\begin{array}{l}\mathrm{N}=73 \text { ninth- } \\
\text { grade students } \\
\text { from } \\
\text { Indonesia }\end{array}$ & $\begin{array}{l}\text { Qualitative } \\
\text { study } \\
\text { Modelling } \\
\text { tests and } \\
\text { interviews }\end{array}$ & $\begin{array}{l}\text { Students } \\
\text { find it } \\
\text { difficult to } \\
\text { model } \\
\text { situations } \\
\text { mathematica }\end{array}$ & \\
\hline
\end{tabular}




\begin{tabular}{|c|c|c|c|c|c|}
\hline Reference & $\begin{array}{l}\text { Focus of } \\
\text { attention }\end{array}$ & $\begin{array}{l}\text { Setting } \\
\text { (informants, } \\
\text { type of } \\
\text { school, } \\
\text { number of } \\
\text { participants) }\end{array}$ & $\begin{array}{l}\text { Method, } \\
\text { data } \\
\text { sources }\end{array}$ & $\begin{array}{l}\text { Implications } \\
\text { for teaching } \\
\text { for } \\
\text { mathematic } \\
\text { al literacy }\end{array}$ & $\begin{array}{l}\text { Recommendati } \\
\text { ons for further } \\
\text { research on } \\
\text { mathematical } \\
\text { literacy }\end{array}$ \\
\hline & $\begin{array}{l}\text { problems } \\
\text { from the } \\
\text { PISA-model } \\
\text { at levels } 5 \\
\text { and } 6\end{array}$ & & & $\begin{array}{l}\text { lly in } \\
\text { problems } \\
\text { and to } \\
\text { evaluate the } \\
\text { reasonablene } \\
\text { ss of a } \\
\text { mathematica } \\
1 \text { solution in } \\
\text { the context } \\
\text { of real-world } \\
\text { problems. } \\
\text { Students } \\
\text { have no } \\
\text { problem in } \\
\text { solving } \\
\text { mathematica } \\
1 \text { problems } \\
\text { they have } \\
\text { constructed. }\end{array}$ & \\
\hline $\begin{array}{l}\text { Gatabi, Stacey } \\
\& \text { Gooya (2012) }\end{array}$ & $\begin{array}{l}\text { Comparison } \\
\text { of Iranian } \\
\text { and } \\
\text { Australian } \\
\text { mathematic } \\
\text { s text-books } \\
\text { Text-book } \\
\text { problems } \\
\text { that show } \\
\text { characteristi } \\
\text { cs } \\
\text { promoting } \\
\text { mathematic } \\
\text { al literacy }\end{array}$ & $\begin{array}{l}\text { Literature } \\
\text { study } \\
\text { Ninth-grade } \\
\text { text-books }\end{array}$ & $\begin{array}{l}\text { Qualitative } \\
\text { research } \\
\text { Content } \\
\text { analysis }\end{array}$ & $\begin{array}{l}\text { Text-books } \\
\text { should } \\
\text { include: } \\
\text { - Problems } \\
\text { with a } \\
\text { variety } \\
\text { of contexts } \\
\text { (real life } \\
\text { and } \\
\text { scientific) } \\
\text { - Problems } \\
\text { without } \\
\text { repetition } \\
\text { of } \\
\text { formulatio } \\
\text { n, but } \\
\text { requiring } \\
\text { more } \\
\text { formulatio } \\
\text { n by } \\
\text { students } \\
\text { - Problems } \\
\text { that are } \\
\text { close to } \\
\text { problem- } \\
\text { solving } \\
\text { - Mathematic }\end{array}$ & $\begin{array}{l}\text { Framework for } \\
\text { identifying how } \\
\text { text-books are } \\
\text { likely to } \\
\text { promote } \\
\text { mathematical } \\
\text { literacy. }\end{array}$ \\
\hline
\end{tabular}




\begin{tabular}{|c|c|c|c|c|c|}
\hline Reference & $\begin{array}{l}\text { Focus of } \\
\text { attention }\end{array}$ & $\begin{array}{l}\text { Setting } \\
\text { (informants, } \\
\text { type of } \\
\text { school, } \\
\text { number of } \\
\text { participants) }\end{array}$ & $\begin{array}{l}\text { Method, } \\
\text { data } \\
\text { sources }\end{array}$ & $\begin{array}{l}\text { Implications } \\
\text { for teaching } \\
\text { for } \\
\text { mathematic } \\
\text { al literacy }\end{array}$ & $\begin{array}{l}\text { Recommendati } \\
\text { ons for further } \\
\text { research on } \\
\text { mathematical } \\
\text { literacy }\end{array}$ \\
\hline & & & & $\begin{array}{l}\text { al } \\
\text { modelling } \\
\text { is the key } \\
\text { process of } \\
\text { mathemati } \\
\text { cal literacy }\end{array}$ & \\
\hline $\begin{array}{l}\text { Höfer\& Beckmann } \\
\text { (2009) }\end{array}$ & $\begin{array}{l}\text { Integrating } \\
\text { science into } \\
\text { mathematic } \\
\text { s education } \\
\text { to promote } \\
\text { functional } \\
\text { thinking } \\
\text { and } \\
\text { mathematic } \\
\text { al literacy }\end{array}$ & $\begin{array}{l}\text { N=300 } \\
\text { Two lessons in } \\
\text { a German } \\
\text { secondary } \\
\text { school, 14-17- } \\
\text { year-old } \\
\text { students }\end{array}$ & $\begin{array}{l}\begin{array}{l}\text { Qualitative } \\
\text { study }\end{array} \\
\text { Observation } \\
\text { (audio and } \\
\text { video } \\
\text { analysis) of } \\
\text { teaching } \\
\text { sequences }\end{array}$ & $\begin{array}{l}\text { To support } \\
\text { mathematica } \\
1 \text { literacy, } \\
\text { teachers } \\
\text { should } \\
\text { devise a } \\
\text { style of } \\
\text { teaching that } \\
\text { includes } \\
\text { conventional } \\
\text { and applied } \\
\text { knowledge. } \\
\text { Scientific } \\
\text { experiments } \\
\text { make it } \\
\text { possible to } \\
\text { create } \\
\text { situations } \\
\text { where } \\
\text { formal } \\
\text { knowledge } \\
\text { and } \\
\text { mathematica } \\
1 \text { activities } \\
\text { can be } \\
\text { combined in } \\
\text { understandi } \\
\text { ng the } \\
\text { subject } \\
\text { matter. }\end{array}$ & $\begin{array}{l}\text { More careful } \\
\text { studies of } \\
\text { students' } \\
\text { abilities by } \\
\text { testing them in } \\
\text { new situations, } \\
\text { and then again } \\
\text { after a few } \\
\text { weeks }\end{array}$ \\
\hline $\begin{array}{l}\text { Ilbagi\&Akgun } \\
\text { (2013) }\end{array}$ & $\begin{array}{l}\text { Investigatio } \\
\mathrm{n} \text { of } \\
\text { students' } \\
\text { mathematic } \\
\text { al literacy in } \\
\text { terms of } \\
\text { PISA } \\
\text { mathematic } \\
\text { al literacy } \\
\text { questions }\end{array}$ & $\begin{array}{l}\mathrm{N}=122715- \\
\text { year-old } \\
\text { students from } \\
\text { Turkey }\end{array}$ & $\begin{array}{l}\text { Quantitative } \\
\text { study } \\
\text { Survey } \\
\text { model. } \\
\text { Analysis of } \\
\text { students' } \\
\text { responses to } \\
\text { a nine- } \\
\text { question test }\end{array}$ & $\begin{array}{l}\text { High school } \\
\text { science } \\
\text { students } \\
\text { show the } \\
\text { highest } \\
\text { performance } \\
\text { in } \\
\text { mathematica } \\
1 \text { literacy, } \\
\text { while }\end{array}$ & $\begin{array}{l}\text { Reasons for the } \\
\text { differences in } \\
\text { results among } \\
\text { different types } \\
\text { of high schools }\end{array}$ \\
\hline
\end{tabular}




\begin{tabular}{|c|c|c|c|c|c|}
\hline Reference & $\begin{array}{l}\text { Focus of } \\
\text { attention }\end{array}$ & $\begin{array}{l}\text { Setting } \\
\text { (informants, } \\
\text { type of } \\
\text { school, } \\
\text { number of } \\
\text { participants) }\end{array}$ & $\begin{array}{l}\text { Method, } \\
\text { data } \\
\text { sources }\end{array}$ & $\begin{array}{l}\text { Implications } \\
\text { for teaching } \\
\text { for } \\
\text { mathematic } \\
\text { al literacy }\end{array}$ & $\begin{array}{l}\text { Recommendati } \\
\text { ons for further } \\
\text { research on } \\
\text { mathematical } \\
\text { literacy }\end{array}$ \\
\hline & & & (PISA 2003). & $\begin{array}{l}\text { general high } \\
\text { school } \\
\text { students and } \\
\text { vocational } \\
\text { high school } \\
\text { students } \\
\text { show the } \\
\text { lowest. }\end{array}$ & \\
\hline $\begin{array}{l}\text { Is } \\
\text { Güzel\&Berberoglu } \\
(2010)\end{array}$ & $\begin{array}{l}\text { Investigatio } \\
\mathrm{n} \text { of } \\
\text { affective } \\
\text { variables } \\
\text { that are } \\
\text { related to } \\
\text { the } \\
\text { mathematic } \\
\text { al literacy } \\
\text { skills of 15- } \\
\text { year-old } \\
\text { Turkish } \\
\text { students in } \\
\text { PISA } 2003\end{array}$ & $\begin{array}{l}\mathrm{N}=485515- \\
\text { year-old } \\
\text { students from } \\
\text { Turkey }\end{array}$ & $\begin{array}{l}\text { Quantitative } \\
\text { study on the } \\
\text { PISA } 2003 \\
\text { dataset for } \\
\text { Turkish } \\
\text { students } \\
\text { Statistical } \\
\text { analysis }\end{array}$ & $\begin{array}{l}\text { The } \\
\text { classroom } \\
\text { climate is } \\
\text { negatively } \\
\text { influenced } \\
\text { by high } \\
\text { anxiety and } \\
\text { low } \\
\text { confidence } \\
\text { levels } \\
\text { among the } \\
\text { students. } \\
\text { The interest } \\
\text { and } \\
\text { enjoyment of } \\
\text { mathematics } \\
\text { among } \\
\text { students was } \\
\text { negatively } \\
\text { related to } \\
\text { mathematica } \\
1 \text { literacy. } \\
\text { This might } \\
\text { be because } \\
\text { learning } \\
\text { achievement } \\
\text { and } \\
\text { mathematica } \\
1 \text { literacy are } \\
\text { not } \\
\text { measured in } \\
\text { the same } \\
\text { way. }\end{array}$ & $\begin{array}{l}\text { There is a need } \\
\text { for closer } \\
\text { investigation of } \\
\text { students' } \\
\text { attitudinal } \\
\text { characteristics } \\
\text { related to school } \\
\text { mathematics } \\
\text { and } \\
\text { mathematical } \\
\text { literacy, and } \\
\text { their impact on } \\
\text { cognitive } \\
\text { measures. }\end{array}$ \\
\hline $\begin{array}{l}\text { Jürges, Schneider, } \\
\text { Senkbeil\&Carstens } \\
\text { en (2012) }\end{array}$ & $\begin{array}{l}\text { The effect of } \\
\text { central exit } \\
\text { exams in } \\
\text { mathematic }\end{array}$ & $\begin{array}{l}\mathrm{N}=4928 \text { ninth- } \\
\text { and tenth- } \\
\text { grade } \\
\text { students(acade }\end{array}$ & $\begin{array}{l}\text { Quantitative } \\
\text { study } \\
\text { Longitudina }\end{array}$ & $\begin{array}{l}\text { Central exit } \\
\text { exams are } \\
\text { significantly } \\
\text { related to }\end{array}$ & \\
\hline
\end{tabular}




\begin{tabular}{|c|c|c|c|c|c|}
\hline Reference & $\begin{array}{l}\text { Focus of } \\
\text { attention }\end{array}$ & $\begin{array}{l}\text { Setting } \\
\text { (informants, } \\
\text { type of } \\
\text { school, } \\
\text { number of } \\
\text { participants) }\end{array}$ & $\begin{array}{l}\text { Method, } \\
\text { data } \\
\text { sources }\end{array}$ & $\begin{array}{l}\text { Implications } \\
\text { for teaching } \\
\text { for } \\
\text { mathematic } \\
\text { al literacy }\end{array}$ & $\begin{array}{l}\text { Recommendati } \\
\text { ons for further } \\
\text { research on } \\
\text { mathematical } \\
\text { literacy }\end{array}$ \\
\hline & $\begin{array}{l}\text { s, students' } \\
\text { mathematic } \\
\text { s } \\
\text { performanc } \\
\text { e and } \\
\text { students' } \\
\text { attitudes } \\
\text { toward } \\
\text { mathematic } \\
\text { s }\end{array}$ & $\begin{array}{l}\text { mic and non- } \\
\text { academic } \\
\text { students) from } \\
\text { Germany }\end{array}$ & $\begin{array}{l}1 \text { study } \\
\text { Data from } \\
\text { PISA-I } \\
\text { study, } \\
\text { mathematica } \\
1 \text { literacy test } \\
\text { and } \\
\text { curricular } \\
\text { knowledge } \\
\text { test } \\
\text { Retested one } \\
\text { year later }\end{array}$ & $\begin{array}{l}\text { better } \\
\text { curricular } \\
\text { knowledge, } \\
\text { but have no } \\
\text { significant } \\
\text { effect on } \\
\text { mathematica } \\
1 \text { literacy. }\end{array}$ & \\
\hline Ko?ar (2015) & $\begin{array}{l}\text { Identificatio } \\
\mathrm{n} \text { of the } \\
\text { direct and } \\
\text { indirect } \\
\text { factors } \\
\text { affecting the } \\
\text { PISA } 2012 \\
\text { mathematic } \\
\text { al literacy }\end{array}$ & $\begin{array}{l}\mathrm{N}=484815- \\
\text { year-old } \\
\text { students from } \\
\text { Turkey }\end{array}$ & $\begin{array}{l}\text { Quantitative } \\
\text { analysis of } \\
\text { the Turkey } \\
\text { sample of } \\
\text { PISA } 2012 \\
\text { (relational } \\
\text { screening } \\
\text { model, } \\
\text { multiple } \\
\text { regression } \\
\text { analysis) }\end{array}$ & $\begin{array}{l}\text { The gender, } \\
\text { economic, } \\
\text { social and } \\
\text { cultural } \\
\text { status index } \\
\text { and time } \\
\text { allocated for } \\
\text { learning } \\
\text { mathematics } \\
\text { independent } \\
\text { variables } \\
\text { have a } \\
\text { significant } \\
\text { influence on } \\
\text { mathematica } \\
1 \text { literacy. }\end{array}$ & $\begin{array}{l}\text { The effect of } \\
\text { more student } \\
\text { activity in } \\
\text { classes, more } \\
\text { teaching of } \\
\text { concepts, } \\
\text { perseverance } \\
\text { regarding } \\
\text { difficult } \\
\text { problems and } \\
\text { more emphasis } \\
\text { on problem- } \\
\text { solving on } \\
\text { mathematical } \\
\text { literacy. }\end{array}$ \\
\hline $\begin{array}{l}\text { Kramarski\& } \\
\text { Mizrachi (2006) }\end{array}$ & $\begin{array}{l}\text { The effects } \\
\text { of online } \\
\text { discussion } \\
\text { embedded } \\
\text { with } \\
\text { metacogniti } \\
\text { ve guidance } \\
\text { on } \\
\text { mathematic } \\
\text { al literacy } \\
\text { and self- } \\
\text { regulated } \\
\text { learning. } \\
\text { Problem- } \\
\text { solving }\end{array}$ & $\begin{array}{l}\mathrm{N}=86 \text { seventh- } \\
\text { grade students } \\
\text { from Israel }\end{array}$ & $\begin{array}{l}\begin{array}{l}\text { Quantitative } \\
\text { study }\end{array} \\
\text { Problem- } \\
\text { solving tasks } \\
\text { Pretest, } \\
\text { posttest, } \\
\text { real-life test } \\
\text { Comparison } \\
\text { group }\end{array}$ & $\begin{array}{l}\text { Students } \\
\text { exposed to } \\
\text { online } \\
\text { discussion } \\
\text { and } \\
\text { metacognitiv } \\
\text { e guidance } \\
\text { attained a } \\
\text { higher level } \\
\text { of } \\
\text { mathematica } \\
1 \text { literacy and } \\
\text { self- } \\
\text { regulated } \\
\text { learning } \\
\text { than those }\end{array}$ & $\begin{array}{l}\text { The need to } \\
\text { understand } \\
\text { more about how } \\
\text { productive } \\
\text { discussion } \\
\text { emerges in } \\
\text { online } \\
\text { communication, } \\
\text { and the need for } \\
\text { researchers to } \\
\text { continue to } \\
\text { define and } \\
\text { examine } \\
\text { features of } \\
\text { communications } \\
\text { that are linked }\end{array}$ \\
\hline
\end{tabular}




\begin{tabular}{|c|c|c|c|c|c|}
\hline Reference & $\begin{array}{l}\text { Focus of } \\
\text { attention }\end{array}$ & $\begin{array}{l}\text { Setting } \\
\text { (informants, } \\
\text { type of } \\
\text { school, } \\
\text { number of } \\
\text { participants) }\end{array}$ & $\begin{array}{l}\text { Method, } \\
\text { data } \\
\text { sources }\end{array}$ & $\begin{array}{l}\text { Implications } \\
\text { for teaching } \\
\text { for } \\
\text { mathematic } \\
\text { al literacy }\end{array}$ & $\begin{array}{l}\text { Recommendati } \\
\text { ons for further } \\
\text { research on } \\
\text { mathematical } \\
\text { literacy }\end{array}$ \\
\hline & & & & $\begin{array}{l}\text { exposed to } \\
\text { face-to-face } \\
\text { discussion, } \\
\text { with or } \\
\text { without } \\
\text { metacognitiv } \\
\text { e guidance. } \\
\text { Instructional } \\
\text { methods on } \\
\text { mathematica } \\
1 \text { literacy are } \\
\text { vital for } \\
\text { increasing } \\
\text { the result. }\end{array}$ & $\begin{array}{l}\text { to qualities of } \\
\text { mutual } \\
\text { engagement, } \\
\text { quality of joint } \\
\text { work, and } \\
\text { individual } \\
\text { learning. }\end{array}$ \\
\hline Lin \& Tai (2015) & $\begin{array}{l}\text { How } \\
\text { various } \\
\text { mathematic } \\
\text { al learning } \\
\text { strategies } \\
\text { affect the } \\
\text { mathematic } \\
\text { al literacy of } \\
\text { students }\end{array}$ & $\begin{array}{l}\mathrm{N}=192,81915- \\
\text { year-old } \\
\text { students from } \\
\text { Taiwan }\end{array}$ & $\begin{array}{l}\text { Quantitative } \\
\text { study } \\
\text { Latent class } \\
\text { analysis of } \\
\text { PISA } 2012 \\
\text { results }\end{array}$ & $\begin{array}{l}\text { Various } \\
\text { learning } \\
\text { strategies } \\
\text { improve } \\
\text { students' } \\
\text { mathematica } \\
1 \text { literacy. } \\
\text { Teachers } \\
\text { must } \\
\text { consider } \\
\text { methods for } \\
\text { explicit } \\
\text { teaching of } \\
\text { these } \\
\text { strategies in } \\
\text { the } \\
\text { classroom. }\end{array}$ & $\begin{array}{l}\text { Further research } \\
\text { on the } \\
\text { relationship } \\
\text { between } \\
\text { learning } \\
\text { strategies and } \\
\text { mathematical } \\
\text { literacy }\end{array}$ \\
\hline Matteson (2006) & $\begin{array}{l}\text { The } \\
\text { frequency } \\
\text { and } \\
\text { categories } \\
\text { of external } \\
\text { representati } \\
\text { ons used to } \\
\text { present and } \\
\text { solve } \\
\text { assessment } \\
\text { items }\end{array}$ & $\begin{array}{l}\text { Third- to } \\
\text { eighth-grade } \\
\text { students } \\
\text { fromthe } \\
\text { United States }\end{array}$ & $\begin{array}{l}\text { Quantitative } \\
\text { study } \\
\text { Analysis of } \\
\text { the } 2003 \text { and } \\
2004 \text { Texas } \\
\text { Assessment } \\
\text { of } \\
\text { Knowledge } \\
\text { and Skills } \\
\text { results(stude } \\
\text { nts solving } \\
\text { algebra } \\
\text { problems) }\end{array}$ & $\begin{array}{l}\text { Representati } \\
\text { ons are } \\
\text { important to } \\
\text { the } \\
\text { development } \\
\text { of } \\
\text { mathematica } \\
1 \text { literacy. By } \\
\text { limiting the } \\
\text { type and } \\
\text { number of } \\
\text { representatio } \\
\text { ns, students } \\
\text { are not given } \\
\text { the }\end{array}$ & $\begin{array}{l}\text { Effectively } \\
\text { developing } \\
\text { mathematical } \\
\text { reading } \\
\text { comprehension } \\
\text { skills, the role of } \\
\text { reading in } \\
\text { developing } \\
\text { problem-solving } \\
\text { strategies and } \\
\text { skills. What } \\
\text { connections } \\
\text { exist between } \\
\text { mathematical } \\
\text { literacy and }\end{array}$ \\
\hline
\end{tabular}




\begin{tabular}{|c|c|c|c|c|c|}
\hline Reference & $\begin{array}{l}\text { Focus of } \\
\text { attention }\end{array}$ & $\begin{array}{l}\text { Setting } \\
\text { (informants, } \\
\text { type of } \\
\text { school, } \\
\text { number of } \\
\text { participants) }\end{array}$ & $\begin{array}{l}\text { Method, } \\
\text { data } \\
\text { sources }\end{array}$ & $\begin{array}{l}\text { Implications } \\
\text { for teaching } \\
\text { for } \\
\text { mathematic } \\
\text { al literacy }\end{array}$ & $\begin{array}{l}\text { Recommendati } \\
\text { ons for further } \\
\text { research on } \\
\text { mathematical } \\
\text { literacy }\end{array}$ \\
\hline & & & & $\begin{array}{l}\text { flexibility or } \\
\text { opportunity } \\
\text { to create } \\
\text { representatio } \\
\text { nal } \\
\text { constructs or } \\
\text { to explain } \\
\text { their } \\
\text { mathematica } \\
1 \text { thinking, } \\
\text { which makes } \\
\text { it difficult to } \\
\text { assess their } \\
\text { level of } \\
\text { mathematica } \\
1 \text { literacy. }\end{array}$ & $\begin{array}{l}\text { reading } \\
\text { comprehension? }\end{array}$ \\
\hline Meaney (2007) & $\begin{array}{l}\text { How } \\
\text { judgements } \\
\text { concerning } \\
\text { mathematic } \\
\text { al literacy } \\
\text { are affected } \\
\text { by } \\
\text { differences } \\
\text { in problem } \\
\text { context }\end{array}$ & $\begin{array}{l}\mathrm{N}=71 \text { fourth- } \\
\text { and eighth- } \\
\text { grade students } \\
\text { from New } \\
\text { Zealand }\end{array}$ & $\begin{array}{l}\text { Qualitative } \\
\text { study } \\
\text { Teachers } \\
\text { administer } \\
\text { tasks at } \\
\text { school. } \\
\text { Videotaped } \\
\text { one-to-one } \\
\text { interviews } \\
\text { in which } \\
\text { teachers } \\
\text { followed a } \\
\text { script and } \\
\text { students had } \\
\text { to explain } \\
\text { how they } \\
\text { would solve } \\
\text { the tasks. }\end{array}$ & $\begin{array}{l}\text { Students' } \\
\text { mathematica } \\
1 \text { thinking } \\
\text { can be } \\
\text { linked to } \\
\text { their levels } \\
\text { of } \\
\text { mathematica } \\
1 \text { literacy. } \\
\text { Context and } \\
\text { demands of } \\
\text { the task } \\
\text { influence the } \\
\text { level of } \\
\text { mathematica } \\
1 \text { literacy } \\
\text { needed. }\end{array}$ & $\begin{array}{l}\text { The relationship } \\
\text { between } \\
\text { language and } \\
\text { mathematical } \\
\text { literacy. Can } \\
\text { providing } \\
\text { students with } \\
\text { specific } \\
\text { instructions } \\
\text { about how to } \\
\text { structure } \\
\text { mathematical } \\
\text { arguments } \\
\text { support their } \\
\text { mathematical } \\
\text { thinking? }\end{array}$ \\
\hline $\begin{array}{l}\text { Ovayolu\&Kutlu } \\
\text { (2011) }\end{array}$ & $\begin{array}{l}\text { Cognitive } \\
\text { dimensions } \\
\text { of } \\
\text { reproductio } \\
\mathrm{n} \text {, } \\
\text { connection } \\
\text { and } \\
\text { reflection } \\
\text { that } \\
\text { constitute } \\
\text { the }\end{array}$ & $\begin{array}{l}\mathrm{N}=494215- \\
\text { year-old } \\
\text { students from } \\
\text { Turkey }\end{array}$ & $\begin{array}{l}\text { Quantitative } \\
\text { study } \\
\text { Analysis of } \\
\text { PISA } 2006 \\
\text { mathematics } \\
\text { sub-test } \\
\text { results }\end{array}$ & $\begin{array}{l}\text { For } \\
\text { implementat } \\
\text { ion of } \\
\text { comprehensi } \\
\text { on strategies, } \\
\text { the scope } \\
\text { and the } \\
\text { content of } \\
\text { the } \\
\text { curriculum } \\
\text { should be }\end{array}$ & $\begin{array}{l}\text { Comparative } \\
\text { studies of PISA } \\
2006 \text { and } 2009 \\
\text { results } \\
\text { Comparative } \\
\text { studies between } \\
\text { Turkey and } \\
\text { other countries }\end{array}$ \\
\hline
\end{tabular}




\begin{tabular}{|c|c|c|c|c|c|}
\hline Reference & $\begin{array}{l}\text { Focus of } \\
\text { attention }\end{array}$ & $\begin{array}{l}\text { Setting } \\
\text { (informants, } \\
\text { type of } \\
\text { school, } \\
\text { number of } \\
\text { participants) }\end{array}$ & $\begin{array}{l}\text { Method, } \\
\text { data } \\
\text { sources }\end{array}$ & $\begin{array}{l}\text { Implications } \\
\text { for teaching } \\
\text { for } \\
\text { mathematic } \\
\text { al literacy }\end{array}$ & $\begin{array}{l}\text { Recommendati } \\
\text { ons for further } \\
\text { research on } \\
\text { mathematical } \\
\text { literacy }\end{array}$ \\
\hline & $\begin{array}{l}\text { students' } \\
\text { mathematic } \\
\text { al thinking } \\
\text { processes }\end{array}$ & & & $\begin{array}{l}\text { based on } \\
\text { real-life } \\
\text { situations. } \\
\text { Practical use } \\
\text { of tools and } \\
\text { materials } \\
\text { should be } \\
\text { emphasized, } \\
\text { as well as } \\
\text { out-of- } \\
\text { school } \\
\text { activities. } \\
\text { There } \\
\text { should be } \\
\text { less focus on } \\
\text { sole } \\
\text { problem- } \\
\text { solving } \\
\text { activities. }\end{array}$ & \\
\hline $\begin{array}{l}\text { Papanastasiou\&Fer } \\
\text { dig (2006) }\end{array}$ & $\begin{array}{l}\text { Relationshi } \\
\text { p between } \\
\text { computer } \\
\text { use and } \\
\text { mathematic } \\
\text { al literacy }\end{array}$ & $\begin{array}{l}\mathrm{N}=213515- \\
\text { year-old } \\
\text { students from } \\
\text { the United } \\
\text { States }\end{array}$ & $\begin{array}{l}\text { Quantitative } \\
\text { study } \\
\text { PISA test } \\
\text { analysis }\end{array}$ & $\begin{array}{l}\text { "Passive" or } \\
\text { mechanical } \\
\text { use of } \\
\text { computers } \\
\text { alone does } \\
\text { not highly } \\
\text { correlate } \\
\text { with } \\
\text { increased } \\
\text { academic } \\
\text { growth. } \\
\text { Some ways } \\
\text { of using } \\
\text { computers } \\
\text { were } \\
\text { associated } \\
\text { with higher } \\
\text { levels of } \\
\text { mathematica } \\
1 \text { literacy } \\
\text { (e.g., } \\
\text { electronic } \\
\text { communicati } \\
\text { on, for } \\
\text { writing }\end{array}$ & $\begin{array}{l}\text { More } \\
\text { experimental } \\
\text { type research on } \\
\text { mathematical } \\
\text { literacy } \\
\text { acquisition and } \\
\text { its relationship } \\
\text { to technology } \\
\text { use. }\end{array}$ \\
\hline
\end{tabular}




\begin{tabular}{|c|c|c|c|c|c|}
\hline Reference & $\begin{array}{l}\text { Focus of } \\
\text { attention }\end{array}$ & $\begin{array}{l}\text { Setting } \\
\text { (informants, } \\
\text { type of } \\
\text { school, } \\
\text { number of } \\
\text { participants) }\end{array}$ & $\begin{array}{l}\text { Method, } \\
\text { data } \\
\text { sources }\end{array}$ & $\begin{array}{l}\text { Implications } \\
\text { for teaching } \\
\text { for } \\
\text { mathematic } \\
\text { al literacy }\end{array}$ & $\begin{array}{l}\text { Recommendati } \\
\text { ons for further } \\
\text { research on } \\
\text { mathematical } \\
\text { literacy }\end{array}$ \\
\hline & & & & $\begin{array}{l}\text { papers). } \\
\text { Other } \\
\text { activities } \\
\text { (e.g., } \\
\text { programmin } \\
\text { g and using } \\
\text { drawing- } \\
\text { type } \\
\text { software) } \\
\text { were } \\
\text { associated } \\
\text { with lower } \\
\text { levels of } \\
\text { mathematica } \\
1 \text { literacy. }\end{array}$ & \\
\hline $\begin{array}{l}\text { Roth, Ercikan, } \\
\text { Simon \&Fola (2015) }\end{array}$ & $\begin{array}{l}\text { To } \\
\text { investigate } \\
\text { possible } \\
\text { linguistic } \\
\text { bias in PISA } \\
\text { items } \\
\text { differentiall } \\
\text { y solved by } \\
\text { students } \\
\text { from } \\
\text { different } \\
\text { language } \\
\text { groups }\end{array}$ & $\begin{array}{l}\mathrm{N}=33 \text { students } \\
\text { (mean age: } \\
15.6 \text { years) } \\
\text { from Canada }\end{array}$ & $\begin{array}{l}\text { Mixed- } \\
\text { method } \\
\text { approach } \\
\text { (multi-level- } \\
\text { analysis of } \\
\text { PISA } \\
\text { mathematics } \\
\text { items, and } \\
\text { think-aloud- } \\
\text { interview } \\
\text { sessions } \\
\text { while } \\
\text { solving the } \\
\text { selected } \\
\text { PISA } \\
\text { mathematics } \\
\text { items) }\end{array}$ & $\begin{array}{l}\text { Think-aloud } \\
\text { situations } \\
\text { offer } \\
\text { students the } \\
\text { opportunity } \\
\text { to express } \\
\text { themselves } \\
\text { much more } \\
\text { than in one- } \\
\text { sentence } \\
\text { responses in } \\
\text { paper-and- } \\
\text { pencil } \\
\text { format. } \\
\text { Conceptual } \\
\text { understandi } \\
\text { ng of what is } \\
\text { at stake is } \\
\text { crucial. }\end{array}$ & $\begin{array}{l}\text { Does PISA } \\
\text { actually assess } \\
\text { conceptual } \\
\text { understanding } \\
\text { and } \\
\text { mathematical } \\
\text { literacy, or: } \\
\text { a) Are } \\
\text { student } \\
\text { s' } \\
\text { answers } \\
\text { someti } \\
\text { mes } \\
\text { based } \\
\text { on } \\
\text { being } \\
\text { familiar } \\
\text { with the } \\
\text { backgro } \\
\text { und } \\
\text { (e.g., } \\
\text { skatebo } \\
\text { arding) } \\
\text { or } \\
\text { knowle } \\
\text { dge of } \\
\text { specific } \\
\text { (technic } \\
\text { al) } \\
\text { words? } \\
\text { b) Does }\end{array}$ \\
\hline
\end{tabular}




\begin{tabular}{|c|c|c|c|c|c|}
\hline Reference & $\begin{array}{l}\text { Focus of } \\
\text { attention }\end{array}$ & $\begin{array}{l}\text { Setting } \\
\text { (informants, } \\
\text { type of } \\
\text { school, } \\
\text { number of } \\
\text { participants) }\end{array}$ & $\begin{array}{l}\text { Method, } \\
\text { data } \\
\text { sources }\end{array}$ & $\begin{array}{l}\text { Implications } \\
\text { for teaching } \\
\text { for } \\
\text { mathematic } \\
\text { al literacy }\end{array}$ & $\begin{array}{l}\text { Recommendati } \\
\text { ons for further } \\
\text { research on } \\
\text { mathematical } \\
\text { literacy }\end{array}$ \\
\hline & & & & & $\begin{array}{l}\text { the } \\
\text { gramma } \\
\text { tical } \\
\text { structur } \\
\text { e create } \\
\text { ambigui } \\
\text { ty or } \\
\text { inhibit } \\
\text { compre } \\
\text { hension } \\
?\end{array}$ \\
\hline Ryan (2013) & $\begin{array}{l}\text { Why has } \\
\text { Australian } \\
\text { school } \\
\text { student } \\
\text { achievemen } \\
\mathrm{t} \text { in reading } \\
\text { and } \\
\text { mathematic } \\
\text { al literacy } \\
\text { fallen in the } \\
\text { PISA } \\
\text { collection } \\
\text { since 2000? }\end{array}$ & $\begin{array}{l}\text { 15-year-old } \\
\text { students from } \\
\text { Australia: } \\
\text { In PISA 2003: } \\
\mathrm{N}=12,551 \\
\text { In PISA 2006: } \\
\mathrm{N}=14,170 \\
\text { In PISA 2009: } \\
\mathrm{N}=14,251\end{array}$ & $\begin{array}{l}\text { Quantitative } \\
\text { analysis of } \\
\text { Australian } \\
\text { PISA studies } \\
\text { from 2003, } \\
2006 \text { and } \\
2009\end{array}$ & $\begin{array}{l}\text { The decline } \\
\text { in } \\
\text { mathematica } \\
1 \text { literacy was } \\
\text { more } \\
\text { pronounced } \\
\text { at the top of } \\
\text { the } \\
\text { distribution } \\
\text { of students } \\
\text { (PISA } 2009 \\
\text { compared } \\
\text { with PISA } \\
\text { 2003). }\end{array}$ & \\
\hline Tai \& Lin (2015) & $\begin{array}{l}\text { The } \\
\text { relationship } \\
\text { between } \\
\text { problem- } \\
\text { solving } \\
\text { styles and } \\
\text { mathematic } \\
\text { al literacy }\end{array}$ & $\begin{array}{l}\mathrm{N}=193,37015- \\
\text { year-old } \\
\text { students from } \\
\text { Taiwan }\end{array}$ & $\begin{array}{l}\text { Quantitative } \\
\text { study } \\
\text { Latent class } \\
\text { analysis of } \\
\text { PISA } 2012 \\
\text { results }\end{array}$ & $\begin{array}{l}\text { Problem- } \\
\text { solving } \\
\text { styles play } \\
\text { an important } \\
\text { role in } \\
\text { mathematica } \\
1 \text { literacy. } \\
\text { Students } \\
\text { who do not } \\
\text { adopt an } \\
\text { active } \\
\text { problem- } \\
\text { solving } \\
\text { attitude have } \\
\text { poorer } \\
\text { mathematica } \\
1 \text { literacy } \\
\text { than those } \\
\text { who do. }\end{array}$ & $\begin{array}{l}\text { Investigating } \\
\text { differences in } \\
\text { problem-solving } \\
\text { skills between } \\
\text { students in } \\
\text { ninth and } \\
\text { tenthgrade, and } \\
\text { between boys } \\
\text { and girls. }\end{array}$ \\
\hline $\begin{array}{l}\text { Tzohar- } \\
\text { Rozen\&Kramarski }\end{array}$ & $\begin{array}{l}\text { The effect of } \\
\text { an affective }\end{array}$ & $\begin{array}{l}\text { Fifth-grade } \\
\text { students from }\end{array}$ & $\begin{array}{l}\text { Mixed } \\
\text { methods }\end{array}$ & $\begin{array}{l}\text { The study } \\
\text { shows that }\end{array}$ & $\begin{array}{l}\text { It is proposed } \\
\text { that: }\end{array}$ \\
\hline
\end{tabular}




\begin{tabular}{|c|c|c|c|c|c|}
\hline Reference & $\begin{array}{l}\text { Focus of } \\
\text { attention }\end{array}$ & $\begin{array}{l}\text { Setting } \\
\text { (informants, } \\
\text { type of } \\
\text { school, } \\
\text { number of } \\
\text { participants) }\end{array}$ & $\begin{array}{l}\text { Method, } \\
\text { data } \\
\text { sources }\end{array}$ & $\begin{array}{l}\text { Implications } \\
\text { for teaching } \\
\text { for } \\
\text { mathematic } \\
\text { al literacy }\end{array}$ & $\begin{array}{l}\text { Recommendati } \\
\text { ons for further } \\
\text { research on } \\
\text { mathematical } \\
\text { literacy }\end{array}$ \\
\hline (2013) & $\begin{array}{l}\text { self- } \\
\text { regulation } \\
\text { programme } \\
\text { on } \\
\text { emotions, } \\
\text { performanc } \\
\text { e in solving } \\
\text { mathematic } \\
\text { al literacy } \\
\text { tasks and } \\
\text { long-term } \\
\text { reflection on } \\
\text { the } \\
\text { programme }\end{array}$ & $\begin{array}{l}\text { Israel: } \\
\mathrm{N}=107 \\
\text { consisting of } \\
54 \text { students in } \\
\text { an affective } \\
\text { self-regulation } \\
\text { group, and } 53 \\
\text { students in a } \\
\text { control group. }\end{array}$ & $\begin{array}{l}\text { Intervention } \\
\text { program, } \\
\text { pre- and } \\
\text { posttest } \\
\text { Factor } \\
\text { analysis and } \\
\text { interviews }\end{array}$ & $\begin{array}{l}\text { the affective } \\
\text { self- } \\
\text { regulation } \\
\text { program } \\
\text { increases } \\
\text { mathematica } \\
1 \text { literacy. } \\
\text { The study } \\
\text { also widens } \\
\text { the } \\
\text { knowledge } \\
\text { of the } \\
\text { emotional } \\
\text { component } \\
\text { of self- } \\
\text { regulation } \\
\text { learning. }\end{array}$ & $\begin{array}{l}\text { - The } \\
\text { effectiveness of } \\
\text { this } \\
\text { intervention } \\
\text { should be } \\
\text { examined in a } \\
\text { variety of } \\
\text { learning } \\
\text { environments, } \\
\text { such as in co- } \\
\text { operative } \\
\text { learning and in } \\
\text { fading } \\
\text { conditions. } \\
\text { - Longitudinal } \\
\text { studies would } \\
\text { also be useful } \\
\text { to determine } \\
\text { the impact. } \\
\text { - A } \\
\text { comprehensive } \\
\text { examination of } \\
\text { interventions } \\
\text { for different } \\
\text { types of } \\
\text { learner (boys } \\
\text { and girls), } \\
\text { students with } \\
\text { different } \\
\text { achievement } \\
\text { levels, students } \\
\text { with learning } \\
\text { disabilities and } \\
\text { student with } \\
\text { math anxiety. }\end{array}$ \\
\hline $\begin{array}{l}\text { Van Hoof, Janssen, } \\
\text { Verschaffel\& Van } \\
\text { Dooren (2015) }\end{array}$ & $\begin{array}{l}\text { Attempt to } \\
\text { develop a } \\
\text { test } \\
\text { instrument } \\
\text { that allows } \\
\text { the } \\
\text { assessment } \\
\text { of density, } \\
\text { operations } \\
\text { and size to } \\
\text { be }\end{array}$ & $\begin{array}{l}\mathrm{N}=213 \text { fourth- } \\
\text { grade students } \\
\text { from nine } \\
\text { schools in } \\
\text { Belgium }\end{array}$ & $\begin{array}{l}\text { Quantitative } \\
\text { analysis of a } \\
\text { paper-and- } \\
\text { pencil test }\end{array}$ & $\begin{array}{l}\text { A good } \\
\text { understandi } \\
\text { ng of size is } \\
\text { a } \\
\text { prerequisite } \\
\text { for gaining } \\
\text { understandi } \\
\text { ng regarding } \\
\text { operations. } \\
\text { This means } \\
\text { that more }\end{array}$ & \\
\hline
\end{tabular}




\begin{tabular}{|c|c|c|c|c|c|}
\hline Reference & $\begin{array}{l}\text { Focus of } \\
\text { attention }\end{array}$ & $\begin{array}{l}\text { Setting } \\
\text { (informants, } \\
\text { type of } \\
\text { school, } \\
\text { number of } \\
\text { participants) }\end{array}$ & $\begin{array}{l}\text { Method, } \\
\text { data } \\
\text { sources }\end{array}$ & $\begin{array}{l}\text { Implications } \\
\text { for teaching } \\
\text { for } \\
\text { mathematic } \\
\text { al literacy }\end{array}$ & $\begin{array}{l}\text { Recommendati } \\
\text { ons for further } \\
\text { research on } \\
\text { mathematical } \\
\text { literacy }\end{array}$ \\
\hline & $\begin{array}{l}\text { combined in } \\
\text { an } \\
\text { integrated } \\
\text { manner }\end{array}$ & & & $\begin{array}{l}\text { attention } \\
\text { should be } \\
\text { paid to } \\
\text { enhancing } \\
\text { pupils' } \\
\text { understandi } \\
\text { ng of the } \\
\text { size of } \\
\text { rational } \\
\text { numbers in } \\
\text { the } \\
\text { classroom. }\end{array}$ & \\
\hline $\begin{array}{l}\text { Van Hoof, } \\
\text { Vandewalle, } \\
\text { Verschaffel\& Van } \\
\text { Dooren (2014) }\end{array}$ & $\begin{array}{l}\text { Rational } \\
\text { numbers are } \\
\text { an essential } \\
\text { part of } \\
\text { mathematic } \\
\text { al literacy, } \\
\text { but cause a } \\
\text { lot of } \\
\text { difficulties } \\
\text { for students } \\
\text { because of a } \\
\text { natural } \\
\text { number bias } \\
\text { (inappropri } \\
\text { ate use of } \\
\text { natural } \\
\text { number } \\
\text { properties } \\
\text { when } \\
\text { learning } \\
\text { about } \\
\text { rational } \\
\text { numbers). }\end{array}$ & $\begin{array}{l}\text { Study 1: } \\
\text { N=291 eighth- } \\
\text { grade students } \\
\text { and an } \\
\text { additional } \\
\mathrm{N}=10 \text { eighth- } \\
\text { grade students } \\
\text { Study 2: } \\
\mathrm{N}=301 \text { tenth- } \\
\text { grade students } \\
\text { andN=305 } \\
\text { twelfth-grade } \\
\text { students } \\
\text { Both studies } \\
\text { from Belgium }\end{array}$ & $\begin{array}{l}\text { Quantitative } \\
\text { and } \\
\text { qualitative } \\
\text { two-cycled } \\
\text { study. } \\
\text { Study } 1 \\
\text { contained a } \\
\text { written test } \\
\text { for all } \\
\text { eighth-grade } \\
\text { students, } \\
\text { followed by } \\
\text { interviews } \\
\text { with } 10 \\
\text { eighth-grade } \\
\text { students } \\
\text { who solved } \\
\text { similar tasks } \\
\text { individually. } \\
\text { Study } 2 \\
\text { contained } \\
\text { the same } \\
\text { written test } \\
\text { for all tenth- } \\
\text { and twelfth- } \\
\text { grade } \\
\text { students. }\end{array}$ & $\begin{array}{l}\text { Students } \\
\text { tend to } \\
\text { doubt the } \\
\text { applicability } \\
\text { of their } \\
\text { natural } \\
\text { number } \\
\text { knowledge } \\
\text { in addition } \\
\text { and } \\
\text { subtraction } \\
\text { items more } \\
\text { than in } \\
\text { multiplicatio } \\
\mathrm{n} \text { and } \\
\text { division } \\
\text { items. }\end{array}$ & \\
\hline $\begin{array}{l}\text { Yilmazer\&Masal } \\
\text { (2014) }\end{array}$ & $\begin{array}{l}\text { Relationshi } \\
\text { p between } \\
\text { seventh- } \\
\text { grade } \\
\text { students' } \\
\text { arithmetic } \\
\text { performanc }\end{array}$ & $\begin{array}{l}\mathrm{N}=297 \\
\text { seventh-grade } \\
\text { students from } \\
\text { Turkey }\end{array}$ & $\begin{array}{l}\text { Quantitative } \\
\text { study } \\
\text { Statistical } \\
\text { analysis }\end{array}$ & $\begin{array}{l}\text { To increase } \\
\text { mathematica } \\
1 \text { literacy, } \\
\text { primary } \\
\text { school } \\
\text { students } \\
\text { should be }\end{array}$ & \\
\hline
\end{tabular}




\begin{tabular}{|c|c|c|c|c|c|}
\hline Reference & $\begin{array}{l}\text { Focus of } \\
\text { attention }\end{array}$ & $\begin{array}{l}\text { Setting } \\
\text { (informants, } \\
\text { type of } \\
\text { school, } \\
\text { number of } \\
\text { participants) }\end{array}$ & $\begin{array}{l}\text { Method, } \\
\text { data } \\
\text { sources }\end{array}$ & $\begin{array}{l}\text { Implications } \\
\text { for teaching } \\
\text { for } \\
\text { mathematic } \\
\text { al literacy }\end{array}$ & $\begin{array}{l}\text { Recommendati } \\
\text { ons for further } \\
\text { research on } \\
\text { mathematical } \\
\text { literacy }\end{array}$ \\
\hline & $\begin{array}{l}\text { e and } \\
\text { mathematic } \\
\text { al literacy }\end{array}$ & & & $\begin{array}{l}\text { presented } \\
\text { with real-life } \\
\text { problems } \\
\text { and open- } \\
\text { ended } \\
\text { interpretatio } \\
\mathrm{n} \text { problems, } \\
\text { and be } \\
\text { enabled to } \\
\text { approach } \\
\text { problems } \\
\text { with a } \\
\text { critical } \\
\text { perspective. } \\
\text { In addition, } \\
\text { qualified } \\
\text { primary } \\
\text { school } \\
\text { teachers who } \\
\text { are engaged } \\
\text { in } \\
\text { mathematics } \\
\text { should be } \\
\text { fostered. }\end{array}$ & \\
\hline $\begin{array}{l}\text { Zhao, Valcke, } \\
\text { Desoete, } \\
\text { Verhaeghe\&Xu } \\
\text { (2011) }\end{array}$ & $\begin{array}{l}\text { Prediction } \\
\text { of } \\
\text { mathematic } \\
\text { s } \\
\text { performanc } \\
\text { e in primary } \\
\text { school }\end{array}$ & $\begin{array}{l}\mathrm{N}=10,959 \\
\text { primary school } \\
\text { students (first- } \\
\text { to sixth-grade) } \\
\text { in China }\end{array}$ & $\begin{array}{l}\text { Quantitative } \\
\text { study } \\
\text { Data } \\
\text { collected } \\
\text { through } \\
\text { written } \\
\text { mathematics } \\
\text { tests on } \\
\text { student } \\
\text { level, } \\
\text { adjusted to } \\
\text { grade level. } \\
\text { Multilevel } \\
\text { approach for } \\
\text { analysis- } \\
\text { school level, } \\
\text { class level, } \\
\text { student } \\
\text { level. }\end{array}$ & $\begin{array}{l}\text { The } \\
\text { acquisition } \\
\text { of } \\
\text { mathematica } \\
1 \text { literacy in } \\
\text { primary } \\
\text { school is a } \\
\text { complex } \\
\text { process } \\
\text { influenced } \\
\text { by a large set } \\
\text { of variables. }\end{array}$ & $\begin{array}{l}\text { Attention may } \\
\text { be paid to } \\
\text { additional } \\
\text { variables at the } \\
\text { school and class } \\
\text { level: school } \\
\text { leadership, } \\
\text { didactical } \\
\text { approaches, } \\
\text { handbooks } \\
\text { used, etc. } \\
\text { Alternative } \\
\text { research designs } \\
\text { such as video- } \\
\text { based analysis } \\
\text { should be } \\
\text { applied to study } \\
\text { teacher quality, } \\
\text { student } \\
\text { engagement, } \\
\text { teacher and } \\
\text { student beliefs, }\end{array}$ \\
\hline
\end{tabular}




\begin{tabular}{|c|c|c|c|c|c|}
\hline Reference & $\begin{array}{l}\text { Focus of } \\
\text { attention }\end{array}$ & $\begin{array}{l}\text { Setting } \\
\text { (informants, } \\
\text { type of } \\
\text { school, } \\
\text { number of } \\
\text { participants) }\end{array}$ & $\begin{array}{l}\text { Method, } \\
\text { data } \\
\text { sources }\end{array}$ & $\begin{array}{l}\text { Implications } \\
\text { for teaching } \\
\text { for } \\
\text { mathematic } \\
\text { al literacy }\end{array}$ & $\begin{array}{l}\text { Recommendati } \\
\text { ons for further } \\
\text { research on } \\
\text { mathematical } \\
\text { literacy }\end{array}$ \\
\hline & & & & & etc. \\
\hline $\begin{array}{l}\text { Zikl, Havlíčkóvá, } \\
\text { Holoubková, } \\
\text { Hrníčková\&Volfov } \\
\text { á (2015) }\end{array}$ & $\begin{array}{l}\text { Comparison } \\
\text { levels of } \\
\text { mathematic } \\
\text { al literacy of } \\
\text { pupils with } \\
\text { mild } \\
\text { intellectual } \\
\text { disabilities } \\
\text { and intact } \\
\text { pupils }\end{array}$ & $\begin{array}{l}\mathrm{N}=48 \text { fourth- } \\
\text { grade students } \\
\text { from the } \\
\text { Czech } \\
\text { Republic }\end{array}$ & $\begin{array}{l}\text { Quantitative } \\
\text { study } \\
\text { Modified } \\
\text { and adjusted } \\
\text { TIMSS tasks } \\
\text { according to } \\
\text { curricular } \\
\text { categories: } \\
\text { - Numbers } \\
\text { - Geometrica } \\
\text { 1 shapes } \\
\text { - Measurem } \\
\text { ents }\end{array}$ & $\begin{array}{l}\text { Enough time } \\
\text { to practice or } \\
\text { take extra } \\
\text { lessons. It is } \\
\text { also } \\
\text { necessary to } \\
\text { reduce } \\
\text { schoolwork, } \\
\text { use } \\
\text { appropriate } \\
\text { teaching } \\
\text { methods, } \\
\text { and } \\
\text { individualiz } \\
\text { e work for } \\
\text { students } \\
\text { with mild } \\
\text { intellectual } \\
\text { disabilities. } \\
\text { Despite such } \\
\text { measures,on } \\
\text { e must } \\
\text { reckon a } \\
\text { significant } \\
\text { difference in } \\
\text { the levels of } \\
\text { mathematica } \\
1 \text { literacy. }\end{array}$ & \\
\hline
\end{tabular}

